\title{
Curriculum vitae of the LOTOS-EUROS (v2.0) chemistry transport model
}

\author{
Astrid M. M. Manders ${ }^{1}$, Peter J. H. Builtjes ${ }^{1,4}$, Lyana Curier ${ }^{1}$, Hugo A. C. Denier van der Gon ${ }^{1}$, Carlijn Hendriks ${ }^{1}$, \\ Sander Jonkers ${ }^{1}$, Richard Kranenburg ${ }^{1}$, Jeroen J. P. Kuenen ${ }^{1}$, Arjo J. Segers ${ }^{1}$, Renske M. A. Timmermans ${ }^{1}$, \\ Antoon J. H. Visschedijk ${ }^{1}$, Roy J. Wichink Kruit ${ }^{2}$, W. Addo J. van Pul ${ }^{2}$, Ferd J. Sauter ${ }^{2}$, Eric van der Swaluw ${ }^{2}$, \\ Daan P. J. Swart ${ }^{2}$, John Douros ${ }^{3}$, Henk Eskes ${ }^{3}$, Erik van Meijgaard ${ }^{3}$, Bert van Ulft $^{3}$, Peter van Velthoven ${ }^{3}$, \\ Sabine Banzhaf ${ }^{4}$, Andrea C. Mues ${ }^{4}$, Rainer Stern ${ }^{4}$, Guangliang Fu ${ }^{5}$, Sha Lu ${ }^{5}$, Arnold Heemink ${ }^{5}$, Nils van Velzen ${ }^{6}$, and \\ Martijn Schaap ${ }^{1,4}$ \\ ${ }^{1}$ TNO, P.O. Box 80015, 3508TA Utrecht, the Netherlands \\ ${ }^{2}$ RIVM, Antonie van Leeuwenhoeklaan 9, 3721 MA Bilthoven, the Netherlands \\ ${ }^{3}$ KNMI, PO Postbus 201, 3730 AE De Bilt, the Netherlands \\ ${ }^{4}$ Institute of Meteorology, Freie Universität, Berlin Carl-Heinrich-Becker-Weg 6-10, 12165, Berlin, Germany \\ ${ }^{5}$ TU Delft, P.O. Box 50312600 GA Delft, the Netherlands \\ ${ }^{6}$ VORtech, Martinus Nijhofflaan 2, 2624 ES Delft, the Netherlands
}

Correspondence to: Astrid M. M. Manders (astrid.manders@tno.nl)

Received: 31 March 2017 - Discussion started: 10 May 2017

Revised: 5 September 2017 - Accepted: 13 September 2017 - Published: 16 November 2017

\begin{abstract}
The development and application of chemistry transport models has a long tradition. Within the Netherlands the LOTOS-EUROS model has been developed by a consortium of institutes, after combining its independently developed predecessors in 2005. Recently, version 2.0 of the model was released as an open-source version. This paper presents the curriculum vitae of the model system, describing the model's history, model philosophy, basic features and a validation with EMEP stations for the new benchmark year 2012, and presents cases with the model's most recent and key developments. By setting the model developments in context and providing an outlook for directions for further development, the paper goes beyond the common model description.

With an origin in ozone and sulfur modelling for the models LOTOS and EUROS, the application areas were gradually extended with persistent organic pollutants, reactive nitrogen, and primary and secondary particulate matter. After the combination of the models to LOTOS-EUROS in 2005, the model was further developed to include new source parametrizations (e.g. road resuspension, desert dust, wildfires), applied for operational smog forecasts in the Netherlands and Europe, and has been used for emission scenarios,
\end{abstract}

source apportionment, and long-term hindcast and climate change scenarios. LOTOS-EUROS has been a front-runner in data assimilation of ground-based and satellite observations and has participated in many model intercomparison studies. The model is no longer confined to applications over Europe but is also applied to other regions of the world, e.g. China. The increasing interaction with emission experts has also contributed to the improvement of the model's performance. The philosophy for model development has always been to use knowledge that is state of the art and proven, to keep a good balance in the level of detail of process description and accuracy of input and output, and to keep a good record on the effect of model changes using benchmarking and validation. The performance of v2.0 with respect to EMEP observations is good, with spatial correlations around 0.8 or higher for concentrations and wet deposition. Temporal correlations are around 0.5 or higher. Recent innovative applications include source apportionment and data assimilation, particle number modelling, and energy transition scenarios including corresponding land use changes as well as Saharan dust forecasting. Future developments would enable more flexibility with respect to model horizontal and vertical resolution and further detailing of model input data. 
This includes the use of different sources of land use characterization (roughness length and vegetation), detailing of emissions in space and time, and efficient coupling to meteorology from different meteorological models.

\section{Introduction}

The most pressing environmental challenges relate to the composition of the atmosphere. Air pollution, climate change and ecosystem degradation have wide-ranging effects on human well-being as well as biodiversity and affect sustainable growth in general. Air pollution has been recognized as harmful to public health and the environment since the 1950s, with the recognition of elevated tropospheric ozone levels in Los Angeles (Haagen-Smit, 1952). The impact of acid deposition was recognized in Europe in the 1950s (Chamberlain, 1953). Whereas air quality was originally regarded as an urban problem, large-scale acidification of soils and surface water as well as summertime ozone episodes have made it clear that air quality was a transboundary problem that needed to be solved at the international level (Eliassen, 1978). Based on this consideration the Convention on Long-Range Transboundary Air Pollution (CLRTAP) was established in 1979. Although emission reduction strategies have been successful for a number of pollutants, air pollution is still an issue. It largely contributes to the burden of lung cancer and respiratory and cardiovascular diseases, which are associated with a considerable decrease in life expectancy (EEA, 2016).

In the early 1970s the first models for air pollution were developed in the US, mainly aimed at studying episodic photochemistry of ozone (e.g. Reynolds et al., 1973). Simultaneously, models aimed at analysing acid deposition were developed in Europe (Rohde, 1972). In the beginning, in the US 3-D Eulerian grid models were preferred while trajectory models were favoured in Europe. The difference was partly motivated by the focus of the models (ozone in the US and deposition in Europe), but the background of the scientists also played a role: atmospheric chemists in the US and meteorologists in Europe. To underpin cost-effective mitigation strategies for air pollution, chemistry transport models were further developed and applied in Europe under the LRTAP convention and within the member states. During the subsequent decades the scope of application of chemistry transport models has increased enormously to study acid rain (e.g. Eliassen and Saltbones, 1983), particulate matter (e.g. Mebust et al., 2003; Schaap et al., 2004b), reactive nitrogen (e.g. Derwent et al., 1989), persistent pollutants (e.g. Pekar et al., 1998) and mercury (e.g. Ryaboshapko et al., 2002).

Besides fundamental research, chemistry transport models (CTMs) are currently used for operational chemical weather forecasting (e.g. Marécal et al., 2015), air quality reanalyses on annual to decadal timescales (e.g. Andersson et al., 2007;
Banzhaf et al., 2015), exploring mitigation measures either by direct comparison of scenario simulations (Thunis et al., 2008,2010 ) or indirectly by providing underlying material for assessment models like GAINS (Amann et al., 2011), climate change through coupling with climate models (e.g. Jacob and Winner, 2009), and modelling of feedbacks between meteorology and aerosols by online coupled numerical weather and chemistry models (e.g. Baklanov et al., 2014), as well as in the design of monitoring strategies using in situ observations or new satellite instruments (e.g. Timmermans et al., 2015). Nowadays, a large number of CTMs exist with a few widely used open-source systems such as EMEP (Simpson et al., 2012), CHIMERE (Menut et al., 2013a; Mailler et al., 2017), WRF-CHEM (Fast et al., 2006; Grell et al., 2005), CMAQ (Byun and Schere, 2006) and CAMx (Environ, 2014).

North America was originally covered by only a few air quality models, but these models had relatively large user communities. In contrast, Europe was covered by a variety of air quality models since many countries or even regions in Europe invested in their own model. These European models each had a relatively small user community. Model intercomparison exercises have contributed to the acceptance of these models and determined the robustness of single model results for policy support purposes (starting with Hass et al., 1997, and continuing with TFMM-EURODELTA, Colette et al., 2017). Nowadays models are more flexible and input has become more standardized so that models can be applied over any continent.

Within the Netherlands the LOTOS-EUROS model has been developed by a consortium of institutes. The model system originates from a merger of two model systems (LongTerm Ozone Simulation, LOTOS, and EUROS, European Operational Smog model) developed individually since the 1980s at TNO (Netherlands Organization for Applied Scientific Research) and RIVM (National Institute for Public Health and the Environment). After integration in 2005 an overview paper was published (Schaap et al., 2008). During the last 10 years there have been numerous changes involving new or revised parameterizations, additional functionalities and application areas. KNMI (Royal Netherlands Meteorological Institute) also came in as a consortium partner for air quality forecasting. In addition, the LOTOS-EUROS system was released in an open-source version in 2016. The reason for it being open-source is to increase the number of users and developers, which would make the basis for the model more solid and would enhance further model development.

In this paper we present LOTOS-EUROS v2.0 and its curriculum vitae (CV). Since the LOTOS-EUROS reference guide is already available at the LOTOS-EUROS website we do not explicitly write out the used parameterizations but merely refer to the relevant literature from which they originate. However, a kind of model CV reflecting the long-term model evolution and model portfolio, as well as a development and benchmarking strategy, has not been published be- 
fore. Such an overview gives a broader perspective on the model philosophy and research directions and is complementary to the regular documentation. This aspect goes beyond other model description papers (e.g. Simpson et al., 2012 for EMEP and Menut et al., 2013a for CHIMERE). First, the model history is presented, relating key developments to societal questions, new scientific knowledge and technical possibilities. Second, the model development and benchmarking strategy is presented. Next, an overview of the model version 2.0 is provided and complemented with the results of the new internal benchmark test. The model portfolio is then sketched with illustrations of special features like source apportionment and data assimilation. Finally possibilities and motivations for further model improvement will be outlined.

\section{History}

\subsection{Origin of LOTOS-EUROS}

LOTOS-EUROS started as two separate models. Since the late 1970s the Dutch institutes RIVM and TNO independently developed their Eulerian models to calculate the dispersion and chemical transformation of air pollutants in the lower troposphere over Europe.

The LOTOS model originates from the US Urban Airshed Model (UAM). In the early 1970s, Steven Reynolds and colleagues in the group of John Seinfeld at Caltech, and later at the private firm Systems Applications Incorporated (SAI), made the pioneering attempts at modelling photochemical air quality (Reynolds et al., 1973). These efforts resulted in the UAM model, a local Eulerian-grid air quality model focused on ozone in episodic situations in urbanized areas. It was first designed to investigate ozone formation over Los Angeles (US). Los Angeles showed the highest peak levels of ozone concentrations that were a major concern in the US, and UAM was used for emission scenario studies. In a cooperation between SAI and TNO, the UAM was modified for application over the Netherlands and its surroundings (Builtjes et al., 1980, 1982). In the beginning of the 1980s, TNO and SAI started cooperation with the FU Berlin (Freie Universität Berlin, Institute of Meteorology) to apply UAM for parts of Germany. In the 1980s the awareness increased that, next to episodic ozone, more long-term values were also of importance. In the US, SAI extended the UAM to cover larger areas and longer periods, which was partly possible due to the increase in computer resources. The new model was subsequently called RTM (Regional Transport Model). RTM is the direct predecessor of LOTOS (Builtjes, 1992). LOTOS contained special features of the original UAM and RTM. It is the vertical structure with a time-varying mixing layer and two reservoir layers which makes the now called LOTOS model unique in its existence. It was later extended with aerosol components (Schaap et al., 2004a, b). The UAM and RTM also formed the basis of the further model develop- ment at the Freie Universität Berlin, leading to the REM (Regional European Model)-Calgrid model (also known as the RCG model, Stern et al., 2003). LOTOS and REM-Calgrid were sister models with intensive exchange of knowledge by their developers.

The Eulerian air quality model EUROS was originally developed at RIVM for the modelling of winter smog $\left(\mathrm{SO}_{2}\right)$ episodes in Europe (van Egmond and Kesseboom, 1981). Later on, the model was used for simulating various airpolluting compounds in the lower troposphere over Europe, such as ozone and persistent organic pollutants (POPs) (Jacobs and Van Pul, 1996). The technical development of EUROS is documented in De Leeuw and Van Rheineck Leyssius (1990), van Rheineck Leyssius et al. (1990), Van Loon (1994, 1995), Hammingh et al. (2001), and Matthijsen et al. (2001).

In both LOTOS and EUROS, aerosols were included around the year 2000 to simulate the inorganic secondary aerosols $\mathrm{SO}_{4}, \mathrm{NH}_{4}$ and $\mathrm{NO}_{3}$ (Schaap et al., 2004a; Erisman and Schaap, 2004; Matthijsen et al., 2002) as well as carbonaceous aerosols (Schaap et al., 2004b). In addition, data assimilation was implemented in LOTOS (Van Loon et al., 2000) and EUROS (Hanea et al., 2004) in collaboration with the same research group at TU Delft. Since the two models had a similar structure and comparable application areas, based on strategic and practical reasoning, RIVM and TNO agreed to collaborate on the development of a single chemistry transport model: LOTOS-EUROS. A pragmatic approach was taken: the backbone of the model was formed by LOTOS with its efficient vertical structure, and for the process descriptions the most advanced scheme of the two models was selected for each process. In 2004 the process of merging the two models was started which resulted in the release of LOTOS-EUROS version 1.0 in 2005 (Schaap et al., 2005, 2008).

\subsection{Development and applications from LOTOS-EUROS v1.0 to v2.0}

After the release of version 1.0 in 2005 the LOTOS-EUROS model has been developed further to be able to (better) respond to new science and policy questions. We have retained the model's specific feature that uses a dynamic boundary layer approach in the vertical direction, handling vertical mixing in a different way than other models and enabling the application of the model over long time spans. The development was facilitated by the increasing quality and detail of input data, better process knowledge, increased computational capacity and advances in remote sensing data. Societal challenges and political attention to adverse health impacts, biodiversity loss and climate change have set the scene for new developments and applications.

The new EU legislation for particulate matter (EC, 1999, with limit values to be met in 2005 and 2010, and its successor EC, 2008, which included $\mathrm{PM}_{2.5}$ ) initiated strong interest 
in establishing the levels and origin of particulate matter during average and episodic conditions. The European monitoring network and methods related to this legislation for $\mathrm{PM}_{10}$, and later on also $\mathrm{PM}_{2.5}$, clearly revealed a systematic gap between observed and modelled concentrations. To improve the model skill for particulate matter the parametrizations for the formation, emission and removal of individual components were revisited. To improve the modelling of secondary inorganic aerosol, updates were made in the schemes for heterogeneous chemistry, cloud chemistry based on Banzhaf et al. (2012) and dry deposition (Zhang et al., 2001). To estimate the natural contribution to PM levels the source parametrization for sea salt was updated (Manders et al., 2010) and the impact of wild fire emissions explored (Martins et al., 2012). This process also led to the introduction of mineral dust in LOTOS-EUROS with emission parametrizations for road resuspension, agricultural land management and wind erosion or desert dust (Schaap et al., 2009). Specific source contributions from, for example, brake wear were addressed with new inventories for tracer components such as copper (Denier van der Gon et al., 2007). Although elemental carbon levels were modelled satisfactorily (Schaap et al., 2004b; Hendriks et al., 2013), a major challenge remained for organic material. Although several schemes for the formation of secondary organic material were tested, no satisfactory model parameterization is available yet. The development of the volatility base set (VBS) approach (Donahue et al., 2006, 2009) in which organic species are organized in volatility classes, with part of the material in aerosol phase and part in the gas phase and allowing for transitions to lower volatility classes due to chemical reactions, seems the most promising approach. It has been implemented in LOTOS-EUROS, but its results still depend heavily on assumptions like the distribution of emissions over volatility bins. To better understand the origin of PM a labelling tool was implemented in LOTOS-EUROS (Kranenburg et al., 2013), which enables the quantification of the contributions of user-specified emission sectors and regions to the modelled mass. Complementary to the model development, emission inventories (e.g. Kuenen et al., 2014) have improved in aspects such as resolution, spatial allocation, consistency and completeness. These inventories have been tested consistently with LOTOS-EUROS (e.g. Timmermans et al., 2013). In short, major advances were made to model particulate matter, although the systematic bias has not been solved yet, mostly due to the challenges remaining for organic aerosol.

Secondary inorganic aerosols have also gained significant attention in light of reactive nitrogen. Current reactive nitrogen emissions to the atmosphere are estimated to be up to 4 times higher than pre-industrial levels and result in a cascade of environmental effects, including adverse health impacts through ozone and particulate matter formation and a loss of biodiversity through eutrophication and acidification of soils and surface waters (Fowler et al., 2013). Prior to the unification of LOTOS and EUROS most attention was given to the formation of secondary inorganic aerosol (e.g. Erisman and Schaap, 2004; Schaap et al., 2004a). Over the following years focus shifted to analysing (the origin of) episodic PM levels with high ammonium nitrate levels (Hendriks et al., 2016b). Reducing ammonia emissions can be effective, as long as ammonia is not present in a large excess (Banzhaf et al., 2013; Hendriks et al., 2016b). Furthermore, the model system was intensively used to assess land-use-specific nitrogen deposition and subsequent critical load exceedances for Germany (Builtjes et al., 2011; Schaap et al., 2017). The deposition modelling was developed further to include the compensation point for ammonia, which describes the net deposition velocity taking into account ammonia re-emissions from the surface (water, soil and vegetation, Wichink Kruit et al., 2010, 2012a) and droplet saturation effects for wet deposition (Banzhaf et al., 2012). These developments resulted in a much larger consistency of the modelled air concentrations and wet deposition fluxes with observations. Large uncertainties still exist in the atmospheric budget of reactive nitrogen species, especially in relation to ammonia (Sutton et al., 2013). This is explained by the short atmospheric lifetime and thus high spatial and temporal variability in ammonia levels combined with a lack of high quality monitoring capacity and large uncertainties in emission distributions. Detailing the temporal emission variability based on meteorology and agricultural practices is pursued to improve the model's skill to capture the intra-annual variability of ammonia (Hendriks et al., 2016b; Kranenburg et al., 2017). Currently, satellite products for ammonia are emerging, which show a great promise for the validation of the LOTOS-EUROS model and its emission information (Van Damme et al., 2014). Besides nitrogen deposition, specific attention has been given to the exposure of terrestrial ecosystems to ozone (phytotoxic ozone dose or PODy, accumulated stomatal ozone flux over a threshold) (Bender et al., 2015) and heavy metals (Nickel et al., 2017). Figure 1 illustrates deposition and PODy applications of LOTOS-EUROS over Germany.

The modest computational demand for running LOTOSEUROS enables many or long term scenarios to be run. LOTOS-EUROS model has been used to evaluate scenarios assuming climate change, energy policies and air quality mitigation policies, as well as land use change scenarios. At first, these were addressed separately. The LOTOSEUROS model was connected to the regional climate model RACMO2 (van Meijgaard et al., 2008) and two scenario simulations covering the gradual transition of climate (19892100) from two global climate models were performed to assess the feedback of climate change on air pollutant concentrations. These simulations showed a significant climate penalty on ozone levels (Manders et al., 2012), whereas none was quantified for particulate matter (Manders et al., 2012; Mues et al., 2013). Also a semi-online coupling between RACMO2 and LOTOS-EUROS was established (Baklanov et al., 2014) and contributed simulations to Phase II of the Air 

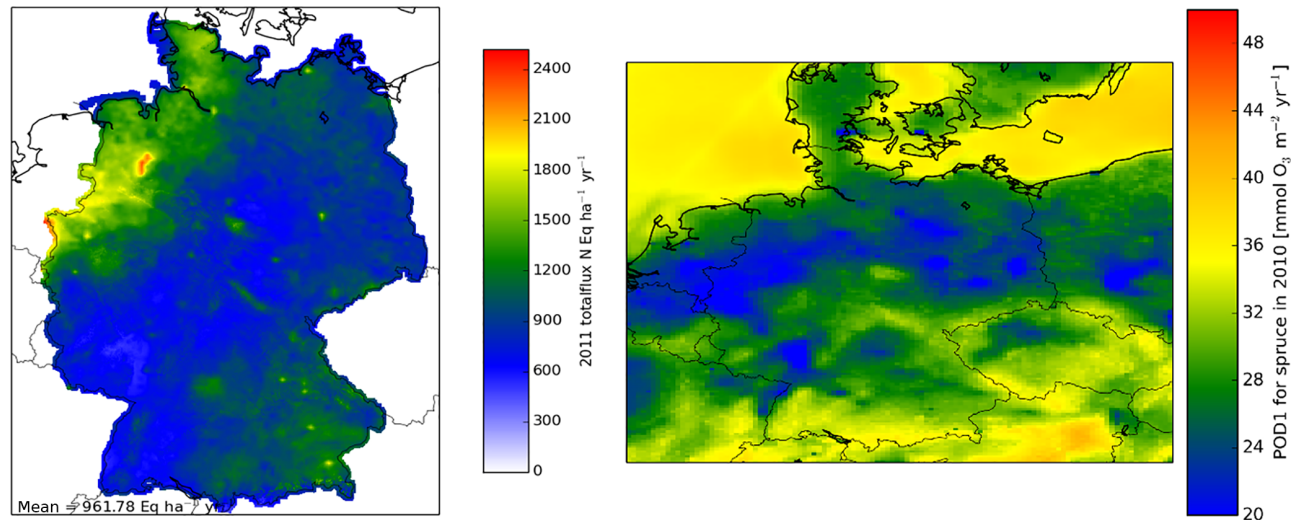

Figure 1. Deposition of nitrogen (oxidized + reduced) over Germany, assessed using the LOTOS-EUROS model in combination with observations of wet deposition (Schaap et al., 2017), and phytotoxic ozone dose for spruce (Bender et al., 2015).

Quality Model Evaluation International Initiative (AQMEII) (Brunner et al., 2014; Im et al., 2015a, b) in which online coupled models were evaluated for simulations of ozone and particulate matter for the year 2010. Also land use change scenarios have been explored with LOTOS-EUROS. The potential impact of future widespread biomass plantations on ozone distributions was highlighted by Beltman et al. (2013). A recent scenario study for ozone showed that the impact of climate policies largely dominates over the concurring impact of land use change and that climate change might counterbalance the impacts of energy policies for ozone (Hendriks et al., 2016a). So far, the common understanding is that, except for ozone, the impact of emission reduction largely exceeds the impact of climate change. However, dynamic evaluation of LOTOS-EUROS showed that it does not fully capture the impact of hotter and dryer summers as occurred in 2003 in Europe on $\mathrm{PM}_{10}$ levels (Mues et al., 2012), indicating that this issue is not fully resolved. A study on the impact of shifting from combustion energy production to solar and wind energy without ample energy storage facilities showed that air quality is less positively affected than is often assumed, since combustion energy is needed to replace solar and wind energy at instances where air pollution accumulation is favoured (Hendriks et al., 2015). In addition, the impact of a transition to a hydrogen economy was evaluated (Popa et al., 2015). To evaluate the ability of LOTOSEUROS to perform scenario studies, the model was used to evaluate air quality trends over the past 25 years (Banzhaf et al., 2015; Colette et al., 2017).

An important development for LOTOS-EUROS was the participation in the EU-FP6 project MACC and its successors. This project was a preparation for the operational Copernicus Atmosphere Monitoring Service (CAMS). This is a European contribution to Global Earth Observation System of Systems (GEOSS) which provides Earth information to a broad range of users. Access to ECMWF analyses and forecasts made it possible to use LOTOS-EUROS for the provision of a daily air quality forecast over Europe and the Netherlands, thereby outperforming and replacing the Dutch statistical models (Manders et al., 2009). In this process KNMI came in as a partner for forecasting activities and assimilation. The air quality forecast was shown to have considerable skill for the first $96 \mathrm{~h}$ (De Ruyter de Wildt et al., 2011). In addition, time-resolved information for boundary conditions and, for example, fire emissions became available. Currently LOTOS-EUROS is part of the regional air quality forecasting and analyses service within the CAMS. This service provides operational forecasts and analyses of ozone, nitrogen dioxide and particulate matter based on an ensemble of seven models (Marécal et al., 2015). The LOTOS-EUROS forecasting service is run at KNMI in an operational weather forecasting environment so that disturbances are quickly resolved, warranting a forecast availability of at least $98 \%$ of time. The forecasting system provides $96 \mathrm{~h}$ forecasts of air quality twice per day. The national service is now delivered through nesting within the European-scale CAMS service. Figure 2 illustrates the data streams and nesting and also shows the necessity for cooperation of the consortium partners. In addition to air pollutants, birch pollen concentrations are forecasted (Sofiev et al., 2015). Currently, near-real-time surface observations of ozone, $\mathrm{NO}_{2}$ and $\mathrm{PM}$ as well as satellite-based OMI tropospheric $\mathrm{NO}_{2}$ column data are assimilated to provide nearreal-time analyses of air quality (Denby et al., 2008; Curier et al., 2012). Assimilation strategies for other components such as $\mathrm{SO}_{2}$ (Barbu et al., 2009) and AOD (Segers et al., 2010) have also been investigated, but are not yet fully operational. The access to global input data has allowed the area of operation to be extended to other regions in the world (e.g. Timmermans et al., 2017). Currently, operational forecasts are delivered for China (http://www.marcopolo-panda. eu/forecast/) and northern Africa (http://sds-was.aemet.es/ forecast-products/dust-forecasts/compared-dust-forecasts). 


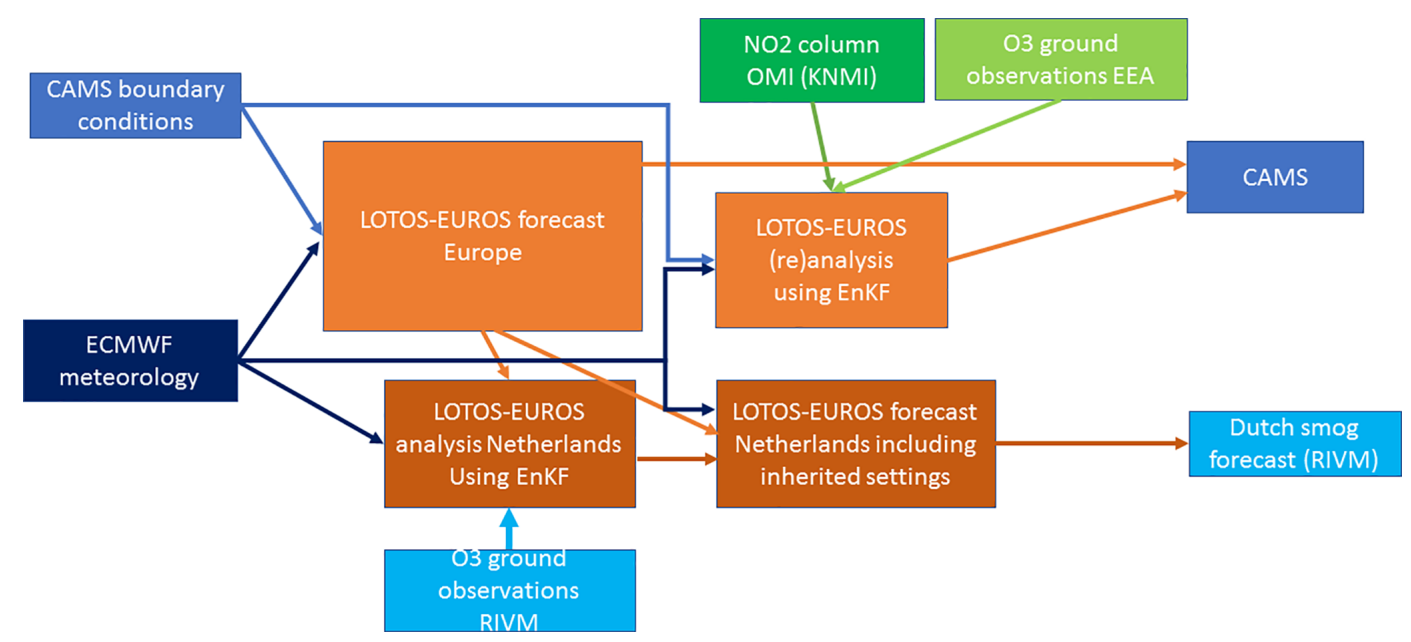

Figure 2. Schematic view of operational suite at KNMI for the production of air quality analysis and forecasts with LOTOS-EUROS for Europe as used for CAMS and for the official Dutch air quality information service as used by RIVM. In data assimilations ground observations of ozone (and $\mathrm{NO}_{2}$ column) are included and the European-scale simulation serves as boundary condition for the higherresolution simulation for the Netherlands. The figure also illustrates the natural cooperation between TNO, KNMI and RIVM for air quality forecasting.

\section{Model development strategy}

\subsection{Philosophy}

The basic philosophy is that the model is both state of the art and reliable, since it has to be used for operational air quality forecasts and policy support applications. Scientific developments are included in the base version of the model after thorough testing of their benefits. This is the reason that we were and still are reluctant in the use of, for example, the VBS approach, as will be argued in Sects. 4.3 and 6.4. Furthermore, the level of detailing of a process in the model should match the general level of detailing of the model, regarding other modelled processes, model resolution and the uncertainties in, for example, meteorological and emission input. On the other hand, the use of the compensation point for $\mathrm{NH}_{3}$, the source apportionment (labelling) approach and data assimilation are features which distinguish LOTOS-EUROS from other models.

\subsection{Version control}

To be able to perform operational calculations, respond to customer requests and to be able to explain differences in model behaviour, a development system has been adopted at TNO. The idea is that the impact of every model development, even as small as an alternative calculation of a meteorological parameter, is traceable. Hence, to document the impact of a development, a benchmark test has to be performed to document the isolated impact of an alteration in the code. Although this approach adds additional workload, it is crucial for quality control, scientific understanding and documentation.
The model development is performed in projects based on a single base version. For each new development, the developer adapts particular pieces of code, which are saved in a separate folder dedicated to the development project. The base code is combined with the altered code in the project folder to build an executable of the model. In this way several developments can be performed at the same time. Compilation of the model code takes place as a part of the initialization of a (test) simulation. The model code, executable and simulation settings file are copied to the model output directory so that every simulation can be reproduced exactly.

Annually, the developments and their impacts are reviewed to select the functionalities which need to be maintained in a new base version. After completion of the new model version the full benchmark test is performed to perform quality assessment and quality control (QAQC) and assess the model performance in a statistical way. Previously, the benchmark test covered the year 2006. With the completion of the open-source version of LOTOS-EUROS the benchmark test was updated covering 2012. The new benchmark test described below was chosen as the measurement data availability has increased in Europe in recent years. Moreover, new input data become available (e.g. CAMS boundary conditions) for recent years, but are normally not provided for historical years. Hence, it appeared practical to start performing the benchmark tests for a more recent year.

\subsection{Model evaluation}

A major aspect of air quality modelling has always been model performance and validation (e.g. Fox, 1981; Rao and Visalli, 1981). Each new model version as well as (dedicated) codes for use in particular projects are evaluated in 
comparison to observations using standard statistical parameters. As such the operational evaluation as defined by Dennis et al. (2010) is executed very often. Dynamic and diagnostic evaluations are much more effort to carry out and are performed occasionally. For example, Mues et al. (2012) addressed the ability of the model system to reproduce the summer of 2003 with its exceptional heat wave, whereas Stern et al. (2008) showed general difficulties of capturing pollutant distributions during very stagnant conditions. Recently, Banzhaf et al. (2015) showed that the model system is able to reproduce nonlinear behaviour observed in trends of secondary inorganic aerosol across Europe. In addition to the traditional model evaluation strategies a new perspective on assessing model performances is through data assimilation. Data assimilation techniques can be used to detect shortcomings in model descriptions and input data (see Sect. 6.1).

Apart from our own validations, LOTOS-EUROS participates as much as possible in model comparison studies in which the model performance is assessed in comparison to its peers. These exercises have increased the interaction with colleagues through dedicated discussions and exchange of experiences and have contributed to the detection of model flaws and subsequent improvement, in particular during the first studies. The first intercomparison was launched within EUROTRAC-GLOREAM (Hass et al., 1997), which was extended into the review of the EMEP model in 2004 (Van Loon et al., 2004). These studies were the basis of the CITYDELTA and EURODELTA studies, in which the robustness of model responses to emission changes was studied with an ensemble of seven chemistry transport models (Van Loon et al., 2007). In addition, LOTOS-EUROS took part in intercomparison studies from COST (Stern et al., 2008) and AQMEII phase I (Solazzo et al., 2012a, b), phase II (Im et al., 2015a, b) and the ongoing phase III and has recently taken part in the EURODELTA phase III (Bessagnet et al., 2016; Garcia Vivanco et al., 2017) and EURODELTA trend analysis, in which several models have simulated the period 1990-2010 (Colette et al., 2017). Through the intercomparison studies the team also benefits from (new) analysis techniques and expertise from a range of scientists. Such an innovation in model evaluation is applied in Solazzo and Galmarini (2016), who analysed results in a new way to investigate behaviour of models on different timescales (seasonal, synoptic, daily, hourly). The model intercomparison studies have demonstrated that a model ensemble generally provides the best performance in comparison to observations, (e.g. Vautard et al., 2009) compared to the performance of individual models, although this requires that models or model versions are independent (Potempski and Galmarini, 2009).

\section{Model description}

This section briefly describes the most important features of the model version v2.0. A more elaborate description can be found in the model documentation (Manders-Groot et al., 2016a)

\subsection{Domain, grid}

LOTOS-EUROS is a regional model on a regular longitudelatitude grid. It is typically used with a resolution of $0.5^{\circ} \times 0.25^{\circ}$ on a domain covering most of Europe and the Mediterranean Sea, but can be applied anywhere and with arbitrary grid resolution, provided that the horizontal resolution is not smaller than about $3 \mathrm{~km}$. This is related to the vertical structure which is quite special to the model. In the vertical direction, the model consists of a static surface layer of $25 \mathrm{~m}$, a dynamic layer extending from $25 \mathrm{~m}$ to the top of the mixing layer, and three dynamic reservoir layers, together filling the vertical between the top of the mixing layer to $5 \mathrm{~km}$ altitude. In earlier version two reservoir layers were often used, with the top of the model domain at $3.5 \mathrm{~km}$ altitude, but also extension to $10 \mathrm{~km}$ has been done by adding more reservoir layers. The mixing layer is defined by the mixing height of the meteorological input and is interpolated in time. It has as a minimum height of $50 \mathrm{~m}$. The lower two reservoir layers are equally thick with a minimum of $500 \mathrm{~m}$, and the third reservoir layer is designed to be $1500 \mathrm{~m}$ thick in order to extend from 3.5 to $5 \mathrm{~km}$, unless the mixing layer is very thick. In the mountains (or the tropics), the mixing layer may extend to more than $3500 \mathrm{~m}$ and the top of the model is extended to fulfil the requirements for minimum thickness of the reservoir layers. The large advantage of the current vertical structure is that it makes the model very efficient in terms of solving the chemistry, the most time-consuming process. However, if higher resolution is desired, the horizontal and vertical dimension could be out of balance for the used parameterizations and more layers have to be added within the mixing layer.

\subsection{Tracers and species}

The model is primarily aimed at air pollution. It models the gas-phase chemistry of ozone $\left(\mathrm{O}_{3}, \mathrm{NO}_{x}\right.$, volatile organic compounds or VOCs, isoprene, $\mathrm{CO}$ ), as well as gas-phase to aerosol conversions of sulfur components $\left(\mathrm{SO}_{2}, \mathrm{SO}_{4}\right)$, reduced nitrogen $\left(\mathrm{NH}_{3}, \mathrm{NH}_{4}\right)$ and oxidized nitrogen $\left(\mathrm{NO}_{3}\right)$. It also explicitly models other primary PM constituents (elemental carbon, organic carbon, other primary PM, mineral dust, sea spray, heavy metals like $\mathrm{Cr}$, base cations like $\mathrm{Ca}$ and $\mathrm{Mg}$ ). There is the possibility to calculate secondary organic aerosol with a 1-D VBS scheme. For climate applications, $\mathrm{CO}_{2}$ can be modelled as a tracer. The required groups of tracers for a simulation can be easily selected, e.g. including or excluding dust or $\mathrm{CO}_{2}$, or modelling only inert species.

\subsection{Chemistry}

The gas-phase chemistry is a condensed version of CBM-IV (Gery et al., 1989), with some modifications in reaction rates, 
and can be found in Manders-Groot et al. (2016a). A kinetic pre-processor is used which makes it relatively straightforward to add or modify chemical reactions. For secondary inorganic chemistry Isorropia II (Fountoukis and Nenes, 2007) is used and for the heterogeneous chemistry on wet aerosol we refer to Wichink Kruit et al. (2012b). A pH-dependent cloud chemistry is also used (Banzhaf et al., 2012). These chemical processes are used by default. Currently secondary organic aerosol is by default not modelled. Given the unrealistically small amounts of SOA added by modules like SORGAM (Schell et al., 2001) that are used by other models the impact of SOA on total modelled particulate matter was too small to enhance model performance. Even more importantly, the uncertainties involved in such approaches may introduce errors. We have now included the option to use the 1-D VBS approach (Donahue et al., 2006) with nine volatility classes in a very conservative way. Anthropogenic emissions of primary organic material are assigned to the four lowest volatility classes and an additional 1.5 times this mass is assigned to the higher five classes. There is no consensus in literature on how emissions should be distributed over the volatility classes. Our choice is based on the idea that emissions of organic material including condensables is 2.5 times the primary organic material reported in the emission inventory (an assumption based on Shrivastava et al., 2008) but with our own constraint that the total of the lower four classes should match the reported primary organic material emissions to be consistent with the default option without VBS. Isoprene and VOC contribute to SOA formation but the impact of terpene is not currently taken into account. Although the impact of the latter is significant due to the relatively high mass of terpene compared to isoprene, emissions and conversion rates are rather uncertain (Bergström et al., 2012; Zhang et al., 2013). Therefore the VBS is not used by default.

\subsection{Meteorology}

LOTOS-EUROS has interfaces to several meteorological model output sets. Atmospheric input fields must cover temperature, wind fields, boundary layer height, cloud cover, vertical distribution, incoming radiation, rain and snow, and specific humidity. In addition the surface properties soil moisture, sea surface temperature and snow/ice coverage are required. These are relevant for sea spray emissions, dust emissions and deposition velocities. The default for the model is 3-hourly ECMWF short-term forecasts meteorology, interpolated to hourly values, but the model has also been run with meteorological input from the regional-scale models WRF (Fast, 2006; Grell, 2005) and HARMONIE (Bengtsson et al., 2017), which run at higher resolution, and has been coupled semi-online to the regional climate model RACMO2 (van Meijgaard et al., 2008). For some slowly changing meteorological drivers, e.g. soil water content, representative average values can be used when they are not directly available from the meteorological model. Friction velocity and Monin-Obhukov length are calculated online based on the land use parameters (roughness length) of LOTOS-EUROS and wind speed, solar zenith angle and cloud cover.

\subsection{Emissions}

Emissions of biogenic NMVOCs (non-methane volatile organic compounds), mineral dust (wind-blown dust and resuspension caused by traffic and agricultural practices) and sea salt are calculated online using meteorology-dependent parameterizations described in Schaap et al. (2009). Sea salt emissions are calculated according to Mårtensson et al. (2003) and Monahan et al. (1986) based on wind speed at $10 \mathrm{~m}$ and sea surface temperature. Hourly emissions from forest fires are taken from the MACC global fire assimilation system (Kaiser et al., 2012). Emissions of NO from soils are included using the parameterization depending on soil type and soil temperature from Novak and Pierce (1993). For the emissions of isoprene and terpene the MEGAN routine is available (Guenther et al., 2006), but for Europe a slightly different approach is taken using a tree species database, as described in Beltman et al. (2013). LOTOS-EUROS calculates online dust emissions based on the sand blasting approach by Marticorena and Bergametti (1995) based on the concept that large sand particles, that are transported horizontally by the wind, hit the ground and then release small dust aerosol particles that are then taken up higher in the atmosphere and contribute to the dust load. The full process description includes the impact of soil moisture and soil composition and uses as input a soil database and a map that indicates the areas that are most prone to emissions due to their topography (potential sources map) (e.g. Mokhtari et al., 2012). Since soil emissions are very sensitive to local conditions the optimal settings depend on the region.

Several sets of anthropogenic emission inventories are available. For applications over Europe, the TNO-MACCIII emission database (available for 2000-2011) is mostly used for the anthropogenic emissions of $\mathrm{NO}_{x}, \mathrm{SO}_{2}, \mathrm{CH}_{4}$, $\mathrm{CO}, \mathrm{NMVOC}, \mathrm{NH}_{3}$, primary $\mathrm{PM}_{2.5}$ and primary $\mathrm{PM}_{10}$ and are therefore used in this study. Primary PM is assigned to the fine and coarse EC, OC and other primary PM tracers using PM split tables. The TNO-MACC-III database is an update from the TNO-MACC-II dataset (Kuenen et al., 2014) and contains high-resolution $\left(0.125 \times 0.0625^{\circ}\right.$ longitudelatitude) gridded emission information based mainly on official country reporting of national emissions to UNECE and the EU. To construct the emission database, reported emissions, presented in aggregated source categories (SNAP levels) as a total annual sum for each country, have been disaggregated spatially using actual point source locations and strengths as well as several proxy maps for area sources (Kuenen et al., 2014). The emission inventory itself contains annual totals of emissions, which have to be distributed over 
time. The temporal disaggregation of emissions is done using sector-specific monthly, daily and hourly time factors and includes temperature-dependent factors for $\mathrm{CO}$ and VOC to account for a cold start for passenger cars. These time factors are part of the model's input and are based on Roemer et al. (2003). In the vertical, fixed emission profile per SNAP code are used (following the approach of EURODELTA, Thunis et al., 2008, see Manders-Groot et al., 2016a for details). If desired, scenario factors on specific countries or source sectors can be defined in a separate file and dedicated emission sets can be integrated without changes to the code. Data from other emission inventories (e.g. EDGAR, EURODELTA emission sets) have been used as well, and can be used without changes in the model code after some preprocessing to meet the rather straightforward input conventions.

\subsection{Land use}

Land use data are an important input parameter to model biogenic emissions of NMVOC, emissions of mineral dust and NO from soils. Moreover, the land use type determines dry deposition characteristics of atmospheric species. We use the Corine2000 Land Cover database (EEA, 2000) with a grid resolution of $0.0167^{\circ}\left(\sim 1.9 \times 1.2 \mathrm{~km}^{2}\right.$ at $\left.50^{\circ} \mathrm{N}\right)$ in longitude and latitude over Europe. This database is complemented with the distribution of 115 tree species over Europe (Koeble and Seufert, 2001). The combined database (which can be updated with Corine2006, EEA, 2007) has a resolution of $0.0166^{\circ} \times 0.0166^{\circ}$ which is aggregated to the required resolution during the start-up of a model simulation. Each grid cell in LOTOS-EUROS is characterized by the fraction of several types of land use in that particular grid cell. A land-sea mask at $0.0089^{\circ}$ longitude-latitude resolution (based on the World Waterbodies GIS map, http://library.duke.edu/data/files/esri/esridm/ 2013/world/data/hydropolys.html) is used to distinguish land area, inland water and seas in more detail. The Black Sea, Caspian Sea and Sea of Azov, labelled "perennial inland water" in the World Waterbodies database were relabelled to "ocean or sea" instead, since they are so large that waves may develop that have significant impact on deposition velocity.

\subsection{Deposition}

Wet deposition is divided between in-cloud and belowcloud scavenging. An in-cloud scavenging module based on the approach described in Seinfeld and Pandis (2006) and Banzhaf et al. (2012) is included, the previous simple belowcloud scavenging approach with scavenging coefficients for aerosols and gases (Simpson et al., 2003; Scott, 1978) was left for backward compatibility. Although the first option is preferred for new simulations, the latter option was used for the simulation in this study as the conservative option to compare with previous versions. For dry deposition, a resis- tance approach is taken. The parameterizations by Zhang et al. (2001) are implemented for particles, and for gases the DEPAC module is used (Van Zanten et al., 2010). Dry deposition velocities are not only used for the calculation of removal of species, but also to translate concentrations at the lowest model level to concentrations at observation height $(2.5 \mathrm{~m})$. This is done by calculating a concentration gradient between observation height and the height at which the deposition velocity is calculated, assuming a constant flux over this part of the column. For $\mathrm{NH}_{3}$ a compensation point approach is implemented (Wichink Kruit et al., 2010, 2012a).

\subsection{Boundary conditions}

Boundary conditions are an essential part of regional models, in particular for components with long lifetime like $\mathrm{CH}_{4}$ and high hemispheric background concentrations like $\mathrm{O}_{3}$. As a basis set, the climatologies by Isaakson and Logan are chosen, with the Mace Head correction for ozone as provided by EMEP (based on Derwent et al., 2007). More detailed boundary conditions can be provided by global models (e.g. TM5) or the global systems in the CAMS system. For operational applications, CAMS boundaries are used for several components. Near-real-time boundary conditions originated from the global MOZART model in the past and for more recent years boundary conditions from the CIFS system (Flemming et al., 2015) are available. When model versions are updated or new data become available for assimilation, the signature of the boundary conditions may change significantly, with large impact on, for example, ozone background levels and thus on model performance of LOTOS-EUROS. As well as to near-real-time boundary conditions, reanalysis data are available from CAMS that provide longer and more consistent series. Which set of boundary conditions is used depends on the application. For high-resolution applications we use a LOTOS-EUROS simulation on a larger domain to nest our smaller high-resolution domain.

\section{Benchmark for 2012}

\subsection{Set-up}

To evaluate LOTOS-EUROS model performance, we use a simulation for 2012 with input datasets specified in Table 1. These inputs are commonly used in LOTOS-EUROS studies. In operational applications, boundary conditions from global models are often used (e.g. MACC products) but their quality depends on the year they are produced. The MACC reanalysis product has brought an improvement on this but seasonal and regional biases were still observed (Katragkou et al., 2015). For this validation study we have chosen to use climatological boundary conditions and the Mace Head correction for ozone based on Derwent et al. (2007), provided by EMEP. This dataset lacks day-to-day variability but has representative monthly average background levels that are 
based on long-term observations. Such climatologies were not available for sea salt and dust. A substantial part of the sea salt is generated internally in LOTOS-EUROS, covering part of the Atlantic. The zero boundary condition will lead to an underestimation of sea salt, mainly at the west coasts of Ireland and Spain. For dust the inflow is highly episodic with high aerosol loads, and the main sources are outside the current modelling domain. Dust products from models covering the Sahara and Middle East are still very uncertain and are therefore not used in this model evaluation. The impact of zero dust boundary conditions will be an underestimation of dust for some episodes mainly in the Mediterranean area.

\subsection{Observation data and evaluation}

The principal source of observation data used in this benchmark is the EMEP network (Tørseth et al., 2012), which provides data from rural and remote measurement stations on an hourly or daily basis. Time series for concentrations of $\mathrm{O}_{3}$, $\mathrm{NO}_{2}, \mathrm{NH}_{3}, \mathrm{SO}_{2}, \mathrm{PM}_{10}, \mathrm{PM}_{2.5}, \mathrm{EC}, \mathrm{Na}$, dust, $\mathrm{NO}_{3}, \mathrm{TNO}_{3}$, $\mathrm{SO}_{4}, \mathrm{NH}_{4}$ and $\mathrm{TNH}_{4}$ were available and were used for the model evaluation. For secondary inorganic aerosols the time series for the EMEP aerosol samplers without inlet specification and $\mathrm{PM}_{10}$ samplers were both used to increase the data availability. In addition, chemical analysis of monthly rainwater samples was used to evaluate the modelled wet depositions. Stations located at an altitude above $700 \mathrm{~m}$ were not considered, and data flags were taken into account by excluding all data points with irregularity. Moreover, a visual screening of the data was performed to assess the quality of the data. Obvious reporting errors, mostly concerning unit conversions, were found and corrected when confirmed through checks with earlier data downloads. A data availability of $>75 \%$ was chosen for a station to be included, which is rather strict but prevents comparison of stations that have operated for only part of the year, omitting for example a full season. Only for $\mathrm{Na}$ and EC the availability criterion was set to $50 \%$ since these require laboratory filter analysis which is for most stations done less often. The observation dataset is frozen as the dataset needs to be used for the validation of future versions for a number of years ahead, and EMEP may update its data. The operational model evaluation was carried out through the calculation of standard statistical measures such as root mean square error (RMSE), bias, and spatial and temporal variability. To reduce the size of the tables, we displayed the average over all stations of the mean and bias of time correlations per station. The spatial correlation is based on annual mean values of all stations. For the performance on individual stations we refer to the validation report (Manders-Groot et al., 2016b).

\subsection{Results}

Annual-average modelled concentrations of $\mathrm{O}_{3}, \mathrm{NO}_{2}, \mathrm{NH}_{3}$, $\mathrm{SO}_{2}, \mathrm{PM}_{10}, \mathrm{PM}_{2.5}, \mathrm{EC}$, sea salt, $\mathrm{NO}_{3}, \mathrm{SO}_{4}$ and $\mathrm{NH}_{4}$ are shown in Fig. 3. They represent the common features related to emission hotspots for emissions related to combustion (large cities, densely populated areas for $\mathrm{NO}_{x}, \mathrm{EC}$ ) and agriculture $\left(\mathrm{NH}_{3}\right.$, most prominently northwestern Europe, southern Germany, Po Valley and Brittany). For $\mathrm{SO}_{2}$ and $\mathrm{SO}_{4}$ Poland and southeastern Europe are dominant, where coal use is relatively large and desulfurization is not applied everywhere. OC concentrations are larger in areas with wood combustion. Ozone shows a pattern that is related to both temperature (increasing concentrations for southern latitudes) combined with lower concentrations in areas with high NO for ozone titration. The secondary inorganic aerosols show a pattern that is a smoothed version of the precursors due their longer lifetime and resulting transport distances. Sea salt clearly shows a strong gradient near the coast, with generation over sea and rapid removal by deposition over land. The zero boundary conditions for sea salt result in unrealistic values at the western boundary of the domain. Not using a dust boundary condition leads to too-low $\mathrm{PM}_{10}$ concentrations in the southern boundary of the domain.

Figure 4 illustrates a time series for ozone (a) and $\mathrm{PM}_{10}$ (b) for a station in the Netherlands, comparing modelled and observed concentrations. Vredepeel is a rural station in a region with intense agriculture and is sometimes influenced by the traffic and household emissions from the nearby and densely populated Ruhr area in Germany. Ozone is slightly overestimated in summer but in general in close agreement with observations, with periods of elevated concentrations during warm conditions. For PM 10 , LOTOS-EUROS generally underestimates the concentrations by a few micrograms per cubic metre but clearly underestimates concentrations in a few peak episodes. These are mostly related to cold and stagnant winter episodes with more emissions and less ventilation. Cold and stagnant conditions are generally an issue for air quality models as input for wind speed, stability and boundary layer height from numerical weather models is not always accurate (Bessagnet et al., 2016). In addition, cold weather leads to more emissions for residential heating, which is not taken into account with the emission time profiles used here. This has in particular impact on the effect of wood burning emissions, that may contribute significant amounts of (secondary or condensable) organic aerosol which is not accounted for in the present emission inventory or accounted for by a SOA implementation.

Table 2 reveals that the spatial correlation, based on the annual mean values for the different stations, is very good for all components, with 0.68 for ozone as the lowest values and values up to 0.95 for $\mathrm{NH}_{3}$. This means that the model is able to represent spatial differences between regions. Spatial correlations for annual mean ozone are relatively poor due the following aspects, which differ per region and station. The annual cycle is strong in the south and weak in the north of Europe and the annual cycle is relatively poorly reproduced for Scandinavian and Baltic stations. Very low night time concentrations for some stations are not captured 
Table 1. Input datasets used in LOTOS-EUROS model run for performance evaluation.

\begin{tabular}{ll}
\hline Input & Dataset \\
\hline Domain & 5 vertical levels $(5 \mathrm{~km}), 35-70^{\circ} \mathrm{N}$, \\
& $15^{\circ} \mathrm{W}-35^{\circ} \mathrm{E}, 0.5^{\circ} \times 0.25^{\circ}$ longitude $\times$ latitude \\
Land cover & Corine/Smiatek (EEA, 2000) combined with \\
& European tree species data Köble and Seufert (2001) \\
Boundary conditions & Climatology + Mace Head correction \\
Meteorology & ECMWF 12 h forecasts \\
Wet deposition description & Below-cloud scavenging coefficients (Scott, 1978) \\
Dry deposition description & Resistance approach. Van Zanten et al. (2010) for gases; Zhang \\
& et al. (2001) for particles; compensation point approach for am- \\
& monia (Wichink Kruit et al., 2010, 2012a) \\
Anthropogenic emissions & TNO-MACC-III \\
Biogenic emissions & Tree species-dependent emission factors for isoprene (Schaap et \\
& al., 2009; Beltman et al., 2013) \\
Soil NO $x$ emissions & Soil-temperature dependent (Novak and Pierce, 1993) \\
Fire emission & MACC/CAMS GFAS product (Kaiser et al., 2012) \\
Dust emissions & Online calculation of natural dust; \\
Sea spray emissions & agricultural activity; road resuspension \\
Gas-phase chemistry & Online \\
Secondary inorganic aerosol & TNO CBM-IV \\
Secondary organic aerosol & Isorropia II (Fountoukis and Nenes, 2007) \\
& Not included \\
\hline
\end{tabular}

by the model and there is an overestimation of baseline concentrations at the western part of the Iberian peninsula due to high boundary conditions. For summer daily maximum and 8-hourly maximum, for which these effects are much reduced, the spatial correlation is indeed very high. This also influences the average performance in time correlations. Time correlations are calculated per station and then averaged, and these averages are quite low, although for many individual stations high correlations for daily maximum and summer 8-hourly maximum are found (e.g. 0.75 for Kollumerwaard). In contrast, despite the excellent spatial correlation, the time correlation for $\mathrm{NH}_{3}$ is one of the poorest. The reason is that emissions of $\mathrm{NH}_{3}$ depend strongly on meteorology in reality (favourable circumstances for manure application, temperature-dependent stable emissions) and $\mathrm{NH}_{3}$ is deposited quickly. In the simulation, long-term average time profiles were used for emissions, and thus day-to-day variations in emissions were not taken into account. In Sect. 6.3 this is explained further. Due to different uncertainties per model component (emissions, chemical conversions, chemical interactions between species, deposition), all modelled species have a different behaviour.

Figure 5 shows modelled annual total wet and dry deposition of oxidized and reduced nitrogen and oxidized sulfur in terms of equivalents per hectare per year, a commonly used unit for ecosystem modelling. For dry deposition fluxes, patterns broadly reflect the emission patterns, smeared out by transport. For wet deposition areas with large precipitation sums (coast and mountain areas) are additional hot spots, particularly visible for oxidized nitrogen. The comparison of modelled monthly-mean rainwater concentrations of $\mathrm{NH}_{4}$, $\mathrm{NO}_{3}$ and $\mathrm{SO}_{4}$ with observations from the EMEP network is in Table 2. The spatial correlation of annual mean concentrations in rainwater across Europe is very good, with values around 0.8 , but the temporal variability of monthly observations per station is poorly reproduced. Figure $4 \mathrm{c}$ illustrates this for Kollumerwaard, a rural station in the north of the Netherlands, close to the Wadden Sea. Annual-average values are underestimated for most stations, although in the time series per station overestimations occur in some months and in other months underestimations occur, resulting in modest time correlation. For wet deposition samples only 12 values per year are available. This limited set of data points drastically reduces the significance of the correlation and eventual outliers are not easily identified. Wet and dry deposition process descriptions are relatively poorly constrained by direct measurements of deposition velocities and scavenging rates. Additional inaccuracies arise from the sometimes local character of rain, which is not captured by the scale of the model and meteorological model input. A detailed discussion and model intercomparison of wet and dry deposition can be found in Garcia Vivanco et al. (2017).

\section{Research areas and innovative applications}

The core of the model is a reliable and efficient calculation of gas-phase and PM components. This core version is the open-source version, that can be obtained after submission of an agreement form on https://lotos-euros.tno.nl/. Here we 

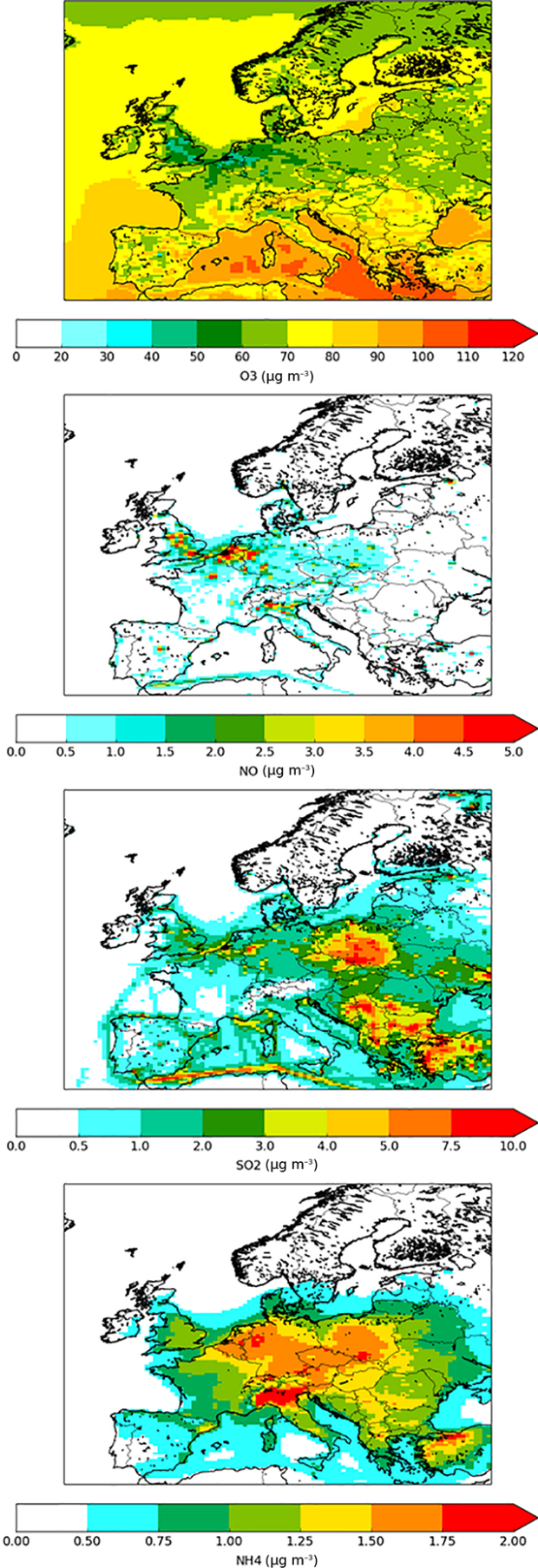

Figure 3.

highlight the model's special functionalities and applications, which are not all part of the open-source version. The source apportionment and particle number modelling features are not part of the open-source version of LOTOS-EUROS v2.0 as they are in the research phase and the code is updated relatively often. The data assimilation system is a separate shell around the model and not part of LOTOS-EUROS itself.
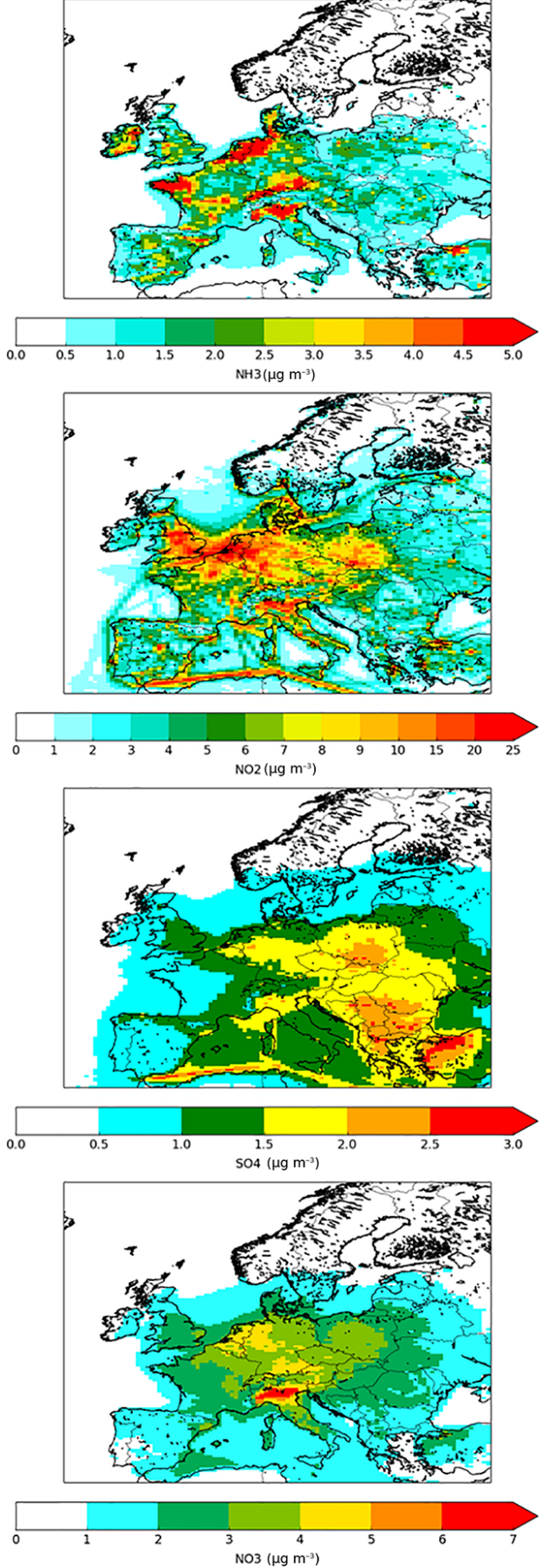

\subsection{Data assimilation system}

A range of techniques can be used to assimilate, or combine, observations with modelled concentration maps for analyses of air pollution situations. Passive data assimilation methods include statistical assimilation techniques such as optimal interpolation methods, residual kriging methods, re- 

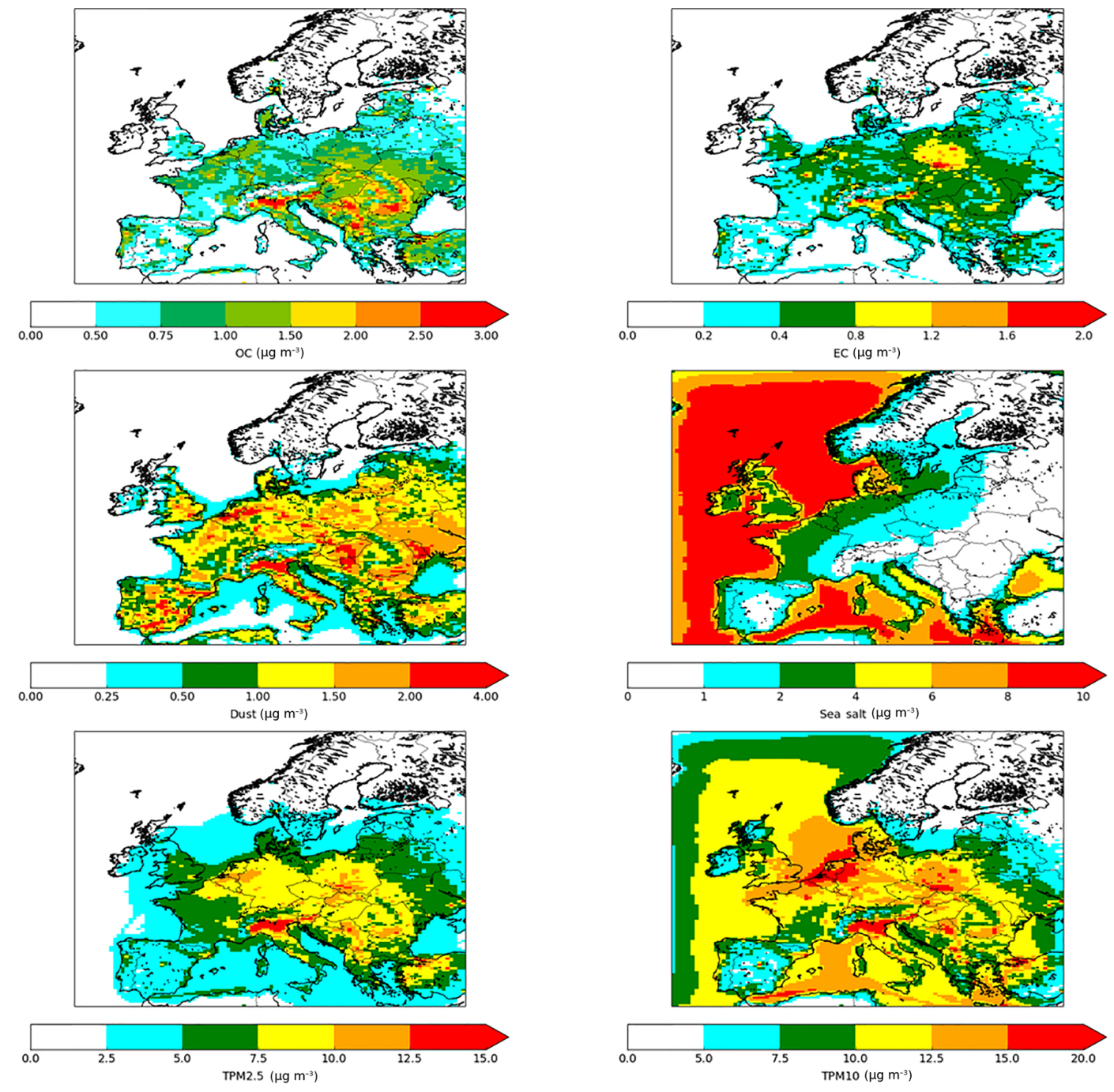

Figure 3. Annual mean surface concentrations for several model species. Note the difference in scaling between the different species and the nonlinear scaling for several species.

gression and multiple regression techniques, e.g. Blond et al. (2003) and Horálek et al. (2005, 2007). These assimilation techniques are most often applied "offline" in the sense that the model output is combined with observations as a post-processing step. Modelled air pollutant distributions of LOTOS-EUROS and its predecessors have regularly been used to investigate new offline methodologies (e.g. Van de Kassteele and Velders, 2006; Van de Kassteele et al., 2006; Hamm et al., 2015) in order to construct the optimal representation of air pollutant concentration or wet deposition fields. These methods can be applied for long-term averages as well as for instantaneous concentration fields. For air quality forecasting applications the positive impact of the data assimilation of observations is usually quickly lost (within 1 day) when only updating the initial state. This is because these techniques do not provide information on uncertain model parameters, such as emissions, that should be adapted to reduce differences between model results and observations.

Additional updates of emissions through active data assimilation have been shown to lead to improvements that last longer (Lahoz et al., 2007; Timmermans et al., 2009; Curier et al., 2012). To allow parameter estimation and further improvements of forecasts, emission monitoring assimilation strategies for air pollutants were developed since the late 1990s. Central to the assimilation of observations with LOTOS-EUROS has been the development of an ensemble Kalman filter system (EnKF) (Evensen, 1994), which allows updates of model parameters, e.g. emissions through the assimilation of observations. In this case an ensemble of model simulations is realized, each with slightly different settings representing the uncertainties in the parameters, and depending on the match with observations the optimal settings can be selected. LOTOS-EUROS with EnKF has been applied 
(a)

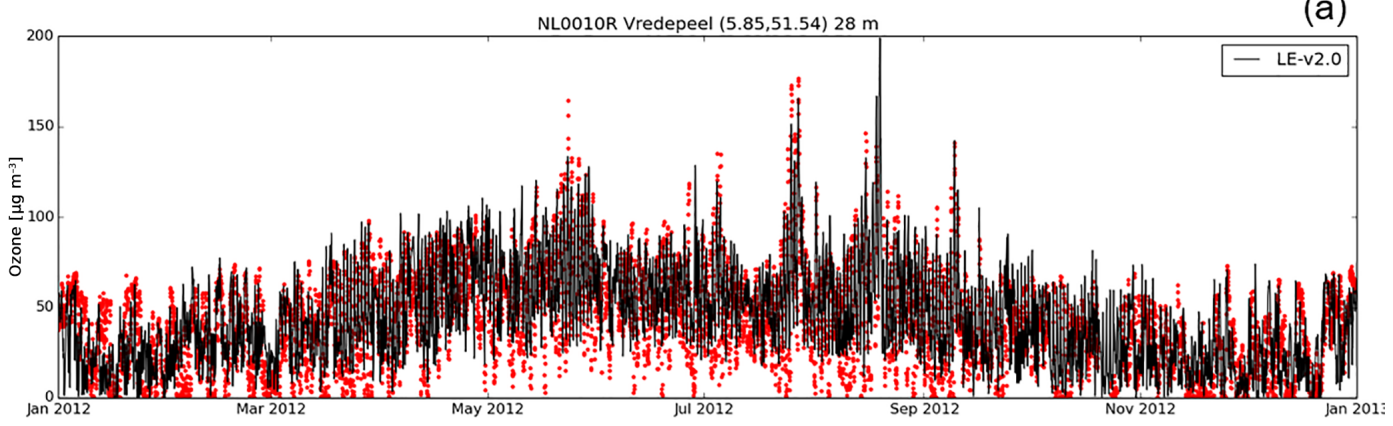

(b)

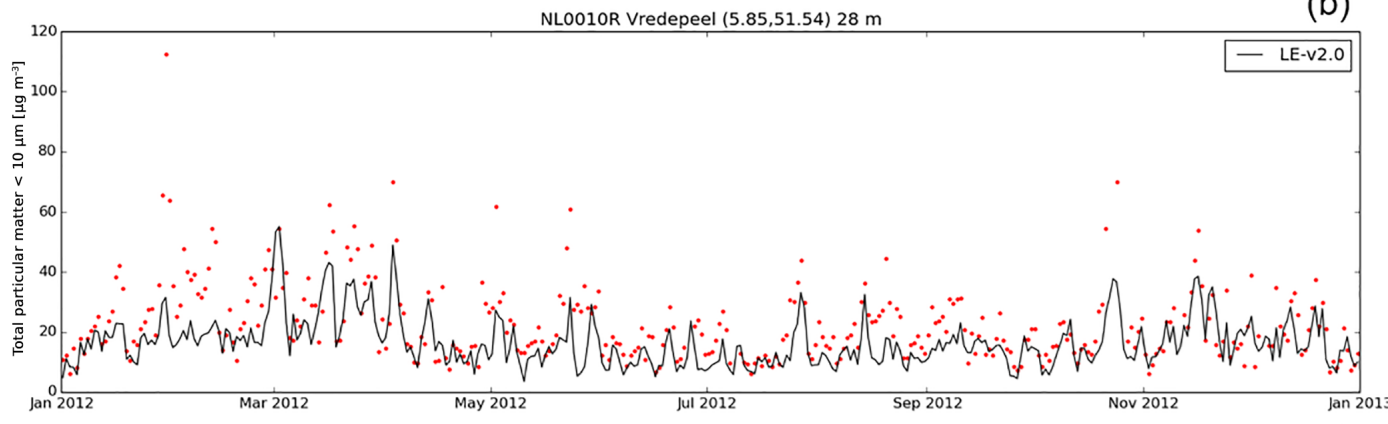

(c)

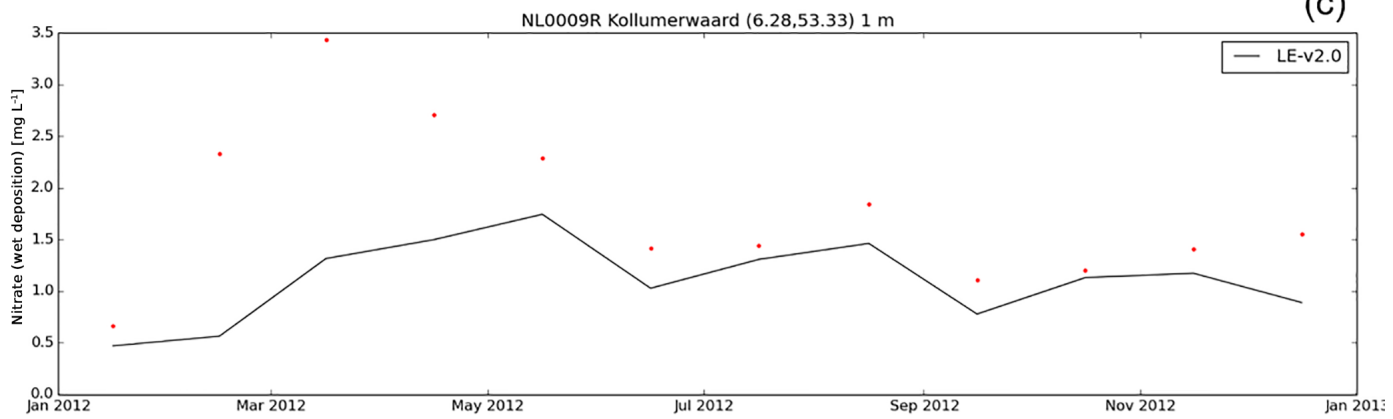

Figure 4. Time series of observed (red dots) and modelled concentrations (black lines) of ozone (a) and $\mathrm{PM}_{10}$ (b) at Vredepeel (the Netherlands, $51.54^{\circ} \mathrm{N}, 5.85^{\circ} \mathrm{E}$ ) and concentrations of $\mathrm{NO}_{3}$ in rainwater (c) in Kollumerwaard (the Netherlands, $53.33^{\circ} \mathrm{N}, 6.28^{\circ} \mathrm{E}$ ).

in a number of applications directed at ozone, sulfur dioxide and/or nitrogen dioxide (e.g. Van Loon et al., 2000; Hanea et al., 2004; Barbu et al., 2009; Van Velzen et al., 2010; Curier et al., 2012) as well as particulate matter (Denby et al., 2008 and Fig. 6) and volcanic ash (Fu et al., 2015). Besides in situ data, satellite tropospheric $\mathrm{NO}_{2}$ column observations (OMI: Eskes et al., 2014) as well as aerosol optical depth (AOD) (SEVIRI: Segers et al., 2010) have been successfully assimilated in the LOTOS-EUROS model. Figure 6 illustrates the improvement in $\mathrm{PM}_{10}$ forecasting by assimilating $\mathrm{PM}_{10}$ ground observations. This example is chosen because it represented an episode with exceptionally high $\mathrm{PM}_{10}$ concentrations over large parts of Europe, that could not be explained by merely changing the emissions of the existing tracers within the ranges of uncertainty. For the baseline concentrations the model performs reasonably well, but for the episode with high concentrations an unspecified tracer had to be added. This tracer could represent large contributions of
SOA from wood burning or wind-blown dust from bare soil during this cold and dry period. The example shows the considerable gain in forecast skill by using data assimilation in the right way.

The assimilation system has also been used to assess the added value of future satellite instruments through so-called Observation System Simulation Experiments (OSSEs, Timmermans et al., 2015). The added value of a future observation system is investigated by producing synthetic observations using a different model simulation (nature run), and assimilate these data in the model. Experience has been obtained for potential new instruments for aerosol optical depth (Timmermans et al., 2009) and nitrogen dioxide (Eskes et al., 2017). To improve the parameter estimation with respect to emission strengths a new direction is to explore variational assimilation techniques that do not require the implementation of the adjoint model of LOTOS-EUROS (Lu et al., 2016). Also, remote sensing has evolved from only detecting 
Table 2. Comparison of modelled and measured concentrations of air pollutants. Bold $=$ based on hourly measurements. regular $=$ based on daily measurements, italic $=$ based on monthly measurements. $\mathrm{O}_{3}$ daymax and $8 \mathrm{hmax}$ are based on April-September. Concentrations in air are reported in micrograms per cubic metre $\left(\mu \mathrm{g} \mathrm{m}^{-3}\right)$. Wet deposition is reported in terms of monthly values of concentrations of SIA in rainwater in milligrams per litre $\left(\mathrm{mg} \mathrm{L}^{-1}\right)$. Mean correlation is mean of time correlation for all stations, spatial correlation is based on annual mean values of all stations.

\begin{tabular}{|c|c|c|c|c|c|c|c|}
\hline Species & $\begin{array}{r}\text { Mean } \\
\text { correlation }\end{array}$ & $\begin{array}{r}\text { Observed } \\
\text { mean }\end{array}$ & $\begin{array}{r}\text { Mean } \\
\text { RMSE }\end{array}$ & $\begin{array}{r}\text { Mean } \\
\text { bias }\end{array}$ & $\begin{array}{r}\text { Measure } \\
\text { for variability } \\
\sigma \mathrm{obs} / \sigma \mathrm{mod}\end{array}$ & $\begin{array}{r}\text { Spatial } \\
\text { correlation } \\
\text { (Pearson) }\end{array}$ & No. of stations \\
\hline $\mathbf{O}_{3}$ & 0.61 & 60.4 & 21.7 & 4.78 & 1.09 & 0.68 & 52 \\
\hline $\mathrm{O}_{3}$ daymax & 0.67 & 91.55 & 16.65 & 6.38 & 1.22 & 0.90 & 51 \\
\hline $\mathrm{O}_{3} 8 \mathrm{hmax}$ & 0.66 & 85.97 & 16.75 & 7.41 & 1.20 & 0.88 & 51 \\
\hline $\mathbf{N O}_{2}$ & 0.44 & 7.83 & 7.24 & 1.69 & 1.16 & 0.91 & 13 \\
\hline $\mathrm{NH}_{3}$ & 0.26 & 1.70 & 1.65 & -0.015 & 1.47 & 0.95 & 13 \\
\hline $\mathbf{S O}_{2}$ & 0.33 & 1.14 & 1.67 & 0.33 & 1.13 & 0.79 & 9 \\
\hline $\mathrm{SO}_{4}$ & 0.52 & 1.58 & 1.21 & -0.61 & 1.63 & 0.87 & 28 \\
\hline $\mathrm{NO}_{3}$ & 0.50 & 2.08 & 2.04 & -0.15 & 1.05 & 0.92 & 15 \\
\hline $\mathrm{NH}_{4}$ & 0.63 & 1.12 & 0.88 & -0.26 & 1.35 & 0.89 & 18 \\
\hline $\mathrm{EC}$ & 0.67 & 1.06 & 0.82 & -0.26 & 2.42 & $(1.0)$ & 2 \\
\hline $\mathrm{Na}$ & 0.53 & 0.81 & 0.75 & 0.29 & 0.85 & 0.93 & 21 \\
\hline $\mathrm{PM}_{2.5}$ & 0.54 & 9.57 & 7.12 & -3.11 & 1.65 & 0.88 & 15 \\
\hline $\mathrm{PM}_{10}$ & 0.46 & 16.02 & 9.92 & -4.93 & 1.79 & 0.81 & 21 \\
\hline $\mathrm{TNH}_{4}$ & 0.50 & 1.18 & 0.74 & -0.066 & 1.19 & 0.90 & 24 \\
\hline wet $\mathrm{NH}_{4}$ & 0.51 & 0.54 & 0.41 & -0.20 & 2.61 & 0.71 & 56 \\
\hline wet $\mathrm{NO}_{3}$ & 0.43 & 1.58 & 1.07 & -0.67 & 2.64 & 0.83 & 56 \\
\hline wet $\mathrm{SO}_{4}$ & 0.28 & 1.18 & 0.95 & -0.78 & 5.43 & 0.69 & 56 \\
\hline
\end{tabular}

Notes: For $\mathrm{SO}_{4}$ and $\mathrm{Na}$, total aerosol matrix was taken (not $\mathrm{PM}_{10}$ ) in order to have more stations available.

AOD to retrievals of microphysical properties like aerosol size and number, which may be assimilated in the future.

\subsection{Source apportionment}

LOTOS-EUROS includes a source apportionment technique to track the origin of air pollutants (Kranenburg et al., 2013). This module tracks the contribution of sources through the model system using a labelling approach similar to Wagstrom et al. (2008). The emissions can be categorized and labelled in several types of categories (e.g. countries, sectors, time of emission) before the model is executed. The labelling routine is implemented for both inert and chemically active tracers containing a C, N (reduced and oxidized) or $\mathrm{S}$ atom. Among other applications, this module was used to study the origin of particulate matter in the Netherlands (Hendriks et al., 2013), changing source receptor relations for energy scenarios in Europe (Hendriks et al., 2015) and particulate matter sources in Chinese cities and regions (Timmermans et al., 2017). Another application was to investigate the sensitivity of the OMI instrument to $\mathrm{NO}_{x}$ emission sources in Europe (Schaap et al., 2013; Curier et al., 2014). The module was also recently used on a high-resolution application for the Netherlands to determine the influence of several source sectors (e.g. shipping, road transport and residential heating) to PM concentrations on a city scale. Figure 7 illustrates the case for Rotterdam, giving detailed in- sight into the contribution of several sectors at specific air concentration levels. By splitting the information into contributions of source regions and sectors, the potential of local measures to reduce air pollution can be quantified and could be used to issue local measures when poor air quality is forecasted.

\subsection{Emissions modelling}

Emissions are partly model input and partly integrated in the model, and therefore we speak of emissions modelling here. Annual totals of anthropogenic emissions are known relatively accurately due to emission reporting obligations and the spatial distribution can be derived from, for example, population density and road networks. These inventories are pure model input data. Natural emissions of sea spray, dust and biogenic VOC are strongly dependent on meteorology and are calculated online. Assessments of emission information can be done by comparing model outcomes with satellite or ground-based observations. This method can be used to check the total quantity of emissions (Curier et al., 2014) or mislocations of sources.

Relatively much improvement in model performance comes from improving the timing of emissions. The distributions of emissions over time are poorly represented by the default time profiles that are used, as they are based on average annual cycles. In a study focused on Germany, timing of 
(a)
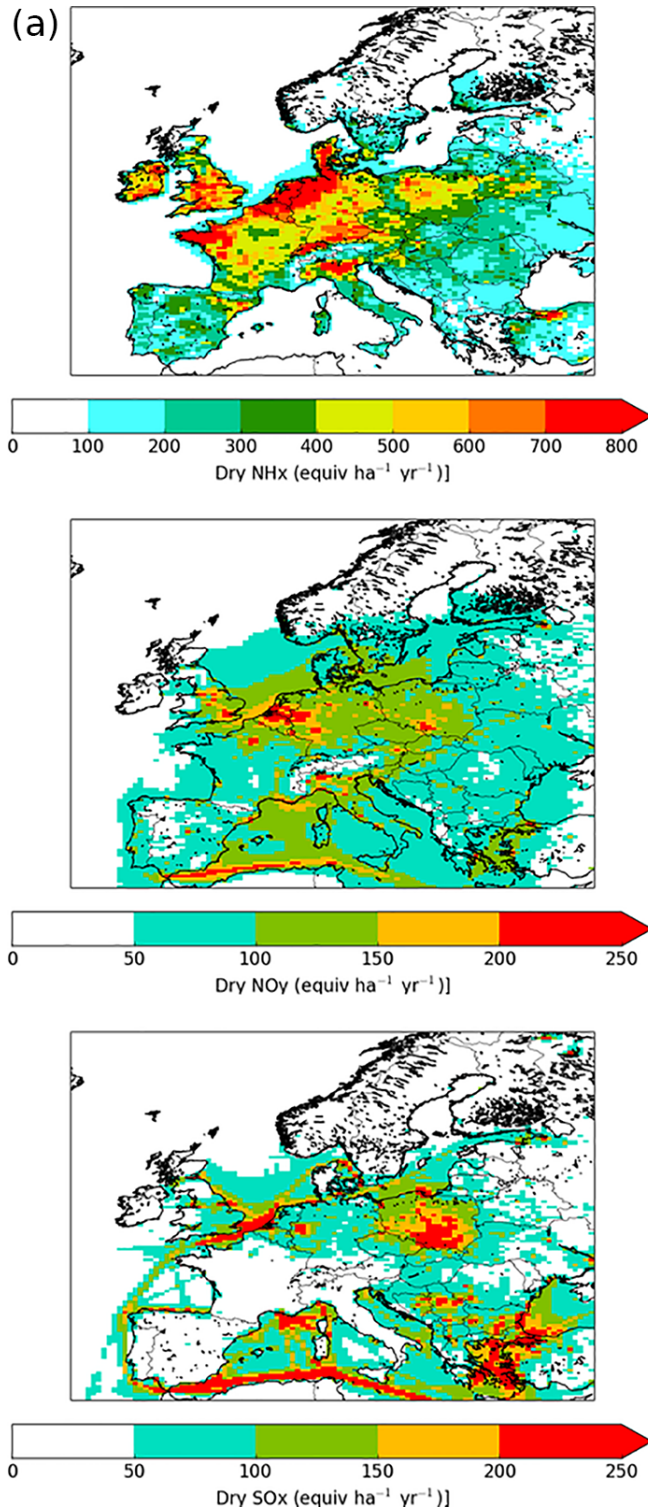

(b)
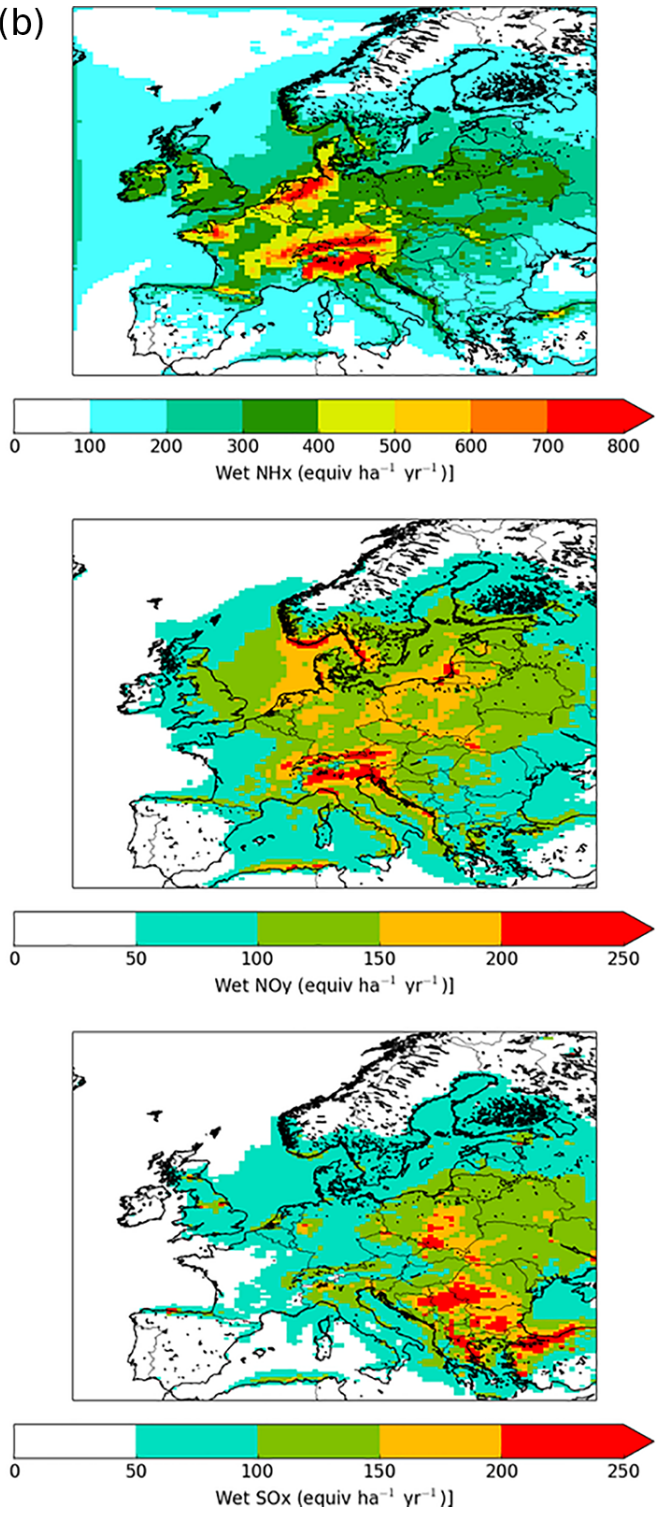

Figure 5. Modelled dry (a) and wet (b) deposition of reduced (top) nitrogen, oxidized (middle) and oxidized sulfur (bottom).

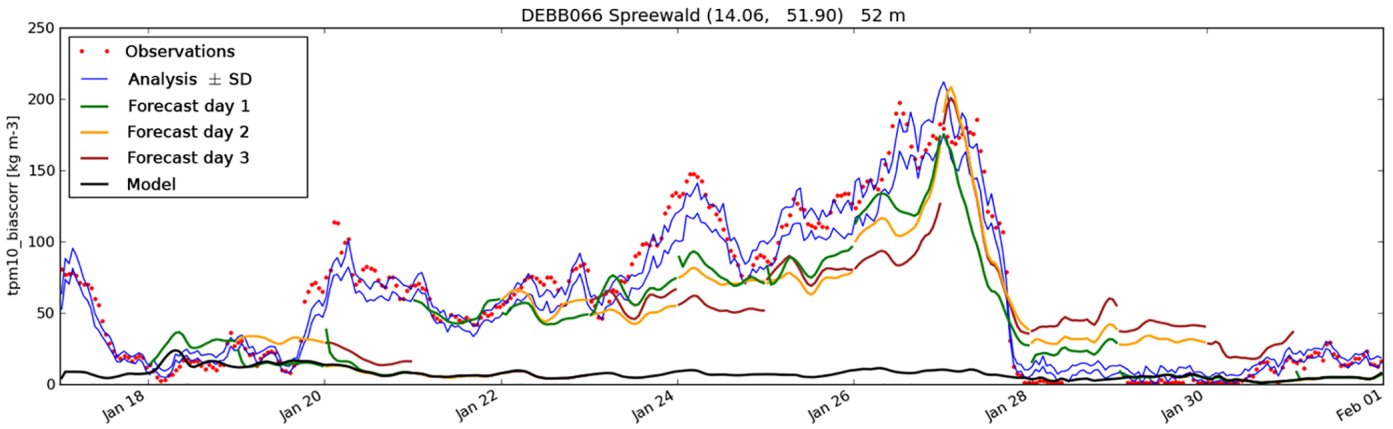

Figure 6. Impact of ground-based $\mathrm{PM}_{10}$ data assimilation on analysis, and 3-day forecast during a large-scale episode of exceptionally high $\mathrm{PM}_{10}$ concentrations over large parts of Europe. 

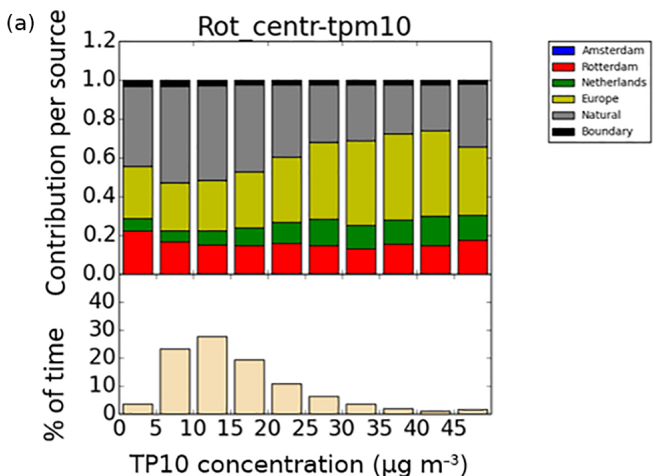

(b)

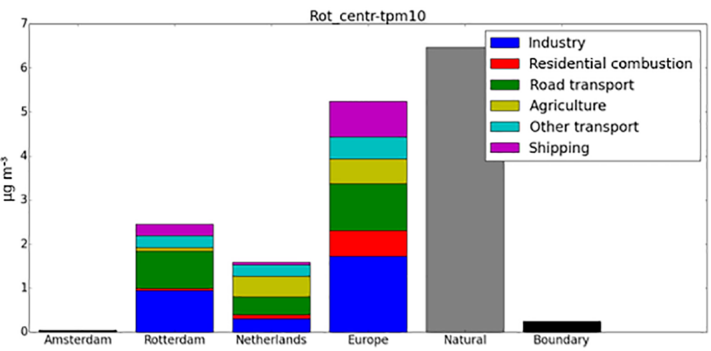

Figure 7. Source apportionment for Rotterdam city centre, 2011. Relative contribution of several source sectors to daily average $\mathrm{PM}_{10}$ concentrations (a) and annual-average absolute contributions of $\mathrm{PM}_{10}$ from several source regions and sectors (b). Note that the natural and boundary contributions have by construction no contributions of sectors or countries.

emissions was improved by using traffic counts for the road transport sector, electricity demand for the power plant emissions and air temperature for redistributing residential combustion emissions (concept of heating degree days), leading to better model performance. When using all new time profiles simultaneously the time correlation coefficient of daily average values increased by $0.05\left(\mathrm{NO}_{2}\right), 0.07\left(\mathrm{SO}_{2}\right)$ and $0.03\left(\mathrm{PM}_{10}\right)$ at urban background stations in Germany (Mues et al., 2014). Ammonia emissions from agriculture are also strongly depending on meteorology (temperature, temperature sums, rain). Figure 8 shows an example where local legislation and meteorology were taken into account in the $\mathrm{NH}_{3}$ emission time profiles (Hendriks et al., 2016b), extending the work of Skjøth et al. $(2004,2011)$. Such advanced timing of anthropogenic emissions is accounted for in a pre-processor of the emissions and not part of the LOTOS-EUROS code. The relatively recent availability of new meteorological variables for soil conditions (moisture, temperature, evaporation) can further improve the timing and amount of natural emissions from soils (more advanced $\mathrm{NO}_{x}$ scheme, and mineral dust, see below) which are calculated online.

\subsection{Aerosol modelling improvement}

There is still a gap between observed and modelled $\mathrm{PM}_{10}$ concentrations. For some species the correspondence with observations is quite good. For others it is more uncertain. Recent developments in aerosol modelling in LOTOSEUROS include the implementation of the VBS scheme; an update of the modelling of desert dust; and the implementation of a module including nucleation, condensation and coagulation to describe particle number concentration and evolution, which are described in the following paragraphs.

LOTOS-EUROS v2.0 has now an implementation of the VBS scheme for secondary organic aerosols as a promising method. The use of previous existing parameterizations (e.g. SORGAM, Schell et al., 2001) did not lead to a significant improvement of model performance in LOTOS-EUROS

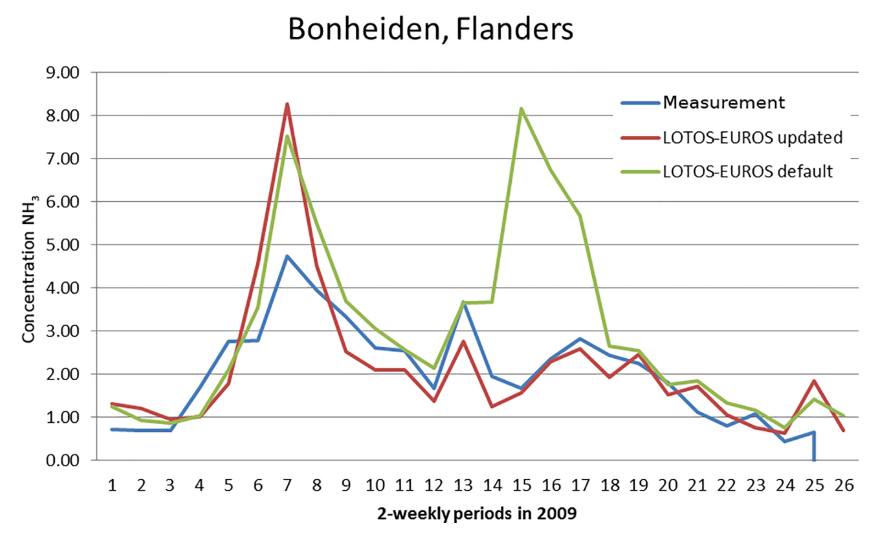

Figure 8. Time series of modelled and measured ammonia concentrations in Bonheiden (Belgium) in 2009, showing the reduction of the unrealistic second $\mathrm{NH}_{3}$ peak of the default simulation around period 16 .

and SOA chemistry was therefore not applied. Model intercomparison studies with models that did include VBS or SORGAM justified this decision. Depending on settings of the model, a wide range of results can still be produced (Bergström et al., 2012). In its current conservative implementation in LOTOS-EUROS, differences with and without VBS are in the order of less than $1 \mu \mathrm{g} \mathrm{m}^{-3}$ (less than $3 \%$ ) on the annual-average concentrations and therefore VBS is not used by default. But when settings and reaction rates become more well established the VBS scheme can be activated or extended.

Mineral dust is the dominant contributor to $\mathrm{PM}_{10}$ in some areas of the world and during specific events. It is generated from deserts but also from bare agricultural soils outside the growing season. Good modelling of mineral dust emissions is a challenge and results from different models are easily a factor of 10 apart. This is because generation of windblown dust is very sensitive to local wind speed and to regional and local roughness length (Menut et al., 2013b) and soil char- 

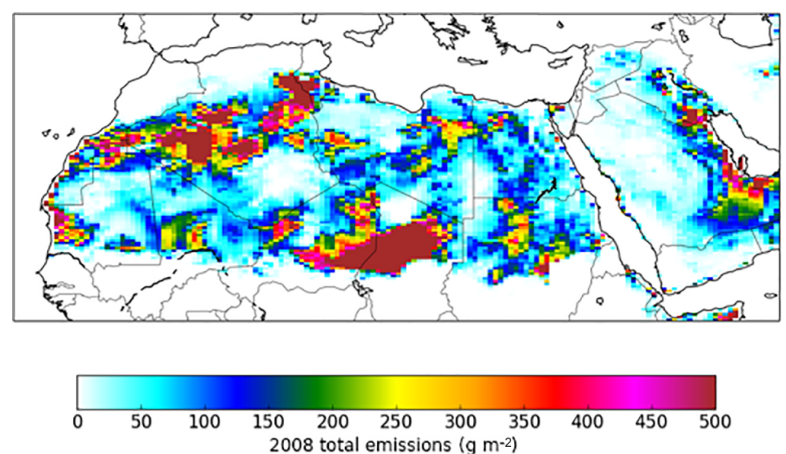
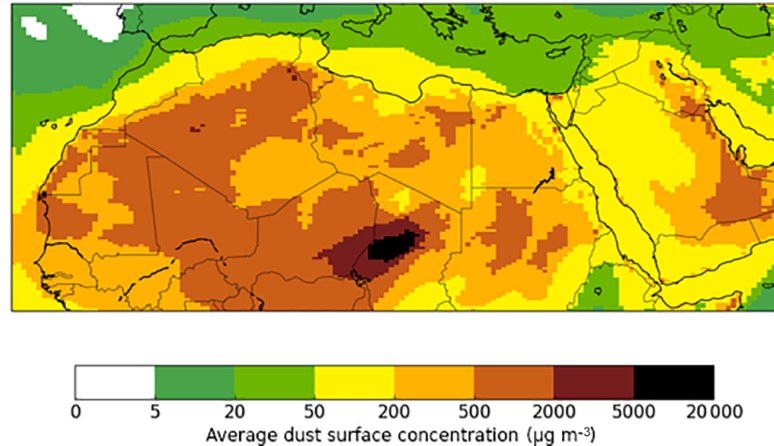

Figure 9. Annual total dust emissions and annual-average dust concentration for 2008.

acteristics (Mokhtari et al., 2012). Therefore all models use tuning factors to come to optimal settings for the region of interest. LOTOS-EUROS has been used to model dust from European dust events (unpublished), from the Gobi desert (Timmermans et al., 2016) and from the Sahara. LOTOSEUROS is part of operational Sand and Dust Storm Warning Advisory and Assessment System (SDS-WAS) for the Northern Africa-Middle East-Europe region since November 2016, see also Fig. 9. LOTOS-EUROS is one of the few models that explicitly includes dust from road resuspension and agricultural activity (input in this moment only available for Europe).

LOTOS-EUROS can use the M7 module (Vignati et al., 2004) to model particle number (PN) concentrations, including the processes of nucleation and condensation of $\mathrm{H}_{2} \mathrm{SO}_{4}$ and coagulation of particles. Particle numbers are dominated by the size range of a few nanometres up to $300 \mathrm{~nm}$ which includes ultrafine particles (UFP, corresponding to $\mathrm{PM}_{0.1}$ ). UFP contribute little to total PM mass but they are relevant since they are abundant and can intrude deeply into the lungs with adverse health effects. Slightly larger particles in the range of $100-300 \mathrm{~nm}$ are relevant for climate modelling as they may grow towards the size of cloud condensation nuclei (e.g. Kulmala et al., 2011; Paasonen et al., 2013). In LOTOSEUROS, M7's original nucleation scheme by Vehkamäki et al. (2002) has been replaced by an activation type (Kulmala et al., 2006) to be more representative of the boundary layer instead of the free troposphere, leading to a better correspondence with observations. The model performance was best for areas that are dominated by anthropogenic sources. For model validation, a description of emission input and application as background model for city-scale models we refer to Kukkonen et al. (2016). The modelled size distribution did not match the observations very well, with an overestimation of small-particle concentrations and an underestimation of large particles. This problem with size distribution was comparable to a similar model application with CAMx (Fountoukis et al., 2012). Nevertheless, the overall total modelled number concentrations were in the right range. It has also been applied at high resolution over the Benelux area (see
Fig. 10), showing the large contribution of road and ship traffic to ultrafine particle concentrations. In general, UFP and PN modelling, as well as PN emission inventories, needed as input, are a recent development for which significant further research is needed.

\section{Discussion and outlook}

The decision to join the Dutch modelling capacity and unite LOTOS and EUROS has proven fruitful. The next step is to extend the user community from the Dutch consortium to a larger group. To facilitate this the model version 2.0 was made available as an open-source model. After 10 years of model development the LOTOS-EUROS model is in good shape and the general performance of v2.0 is satisfactory. In model intercomparison studies LOTOS-EUROS falls well within the range of other models and is for some species among the best-performing models (see e.g. Bessagnet et al., 2016; Im et al., 2015a, b for the performance of recent previous versions). These studies also show that there is no single model that is best for all species. During its development from v1.0 to v2.0 LOTOS-EUROS has retained the original set-up with the efficient layer system, and the model can be applied for both operational forecasts and long-term climate and scenario applications. The labelling technique and data assimilation make LOTOS-EUROS stand out. There are several lines of research for further improvement.

A large remaining issue is the general underestimation of PM mass by LOTOS-EUROS, a feature that is shared by most chemistry transport models. In v2.0 this underestimation of $\mathrm{PM}_{10}$ was reduced compared to previous versions, amongst others by a change in deposition velocity for arable land outside the growing season, new meteorological input data, and taking soil $\mathrm{NO}_{x}$ emissions into account. To further improve upon this, we need to further develop several aspects of the model that we will discuss now. Model evaluation showed that secondary inorganic aerosols were underestimated on average, in particular $\mathrm{SO}_{4}$ and $\mathrm{NH}_{4}$ and to a minor extent $\mathrm{NO}_{3}$. Part of the $\mathrm{SO}_{4}$ underestimation is related to PM peak episodes in winter, and thus related to issues 

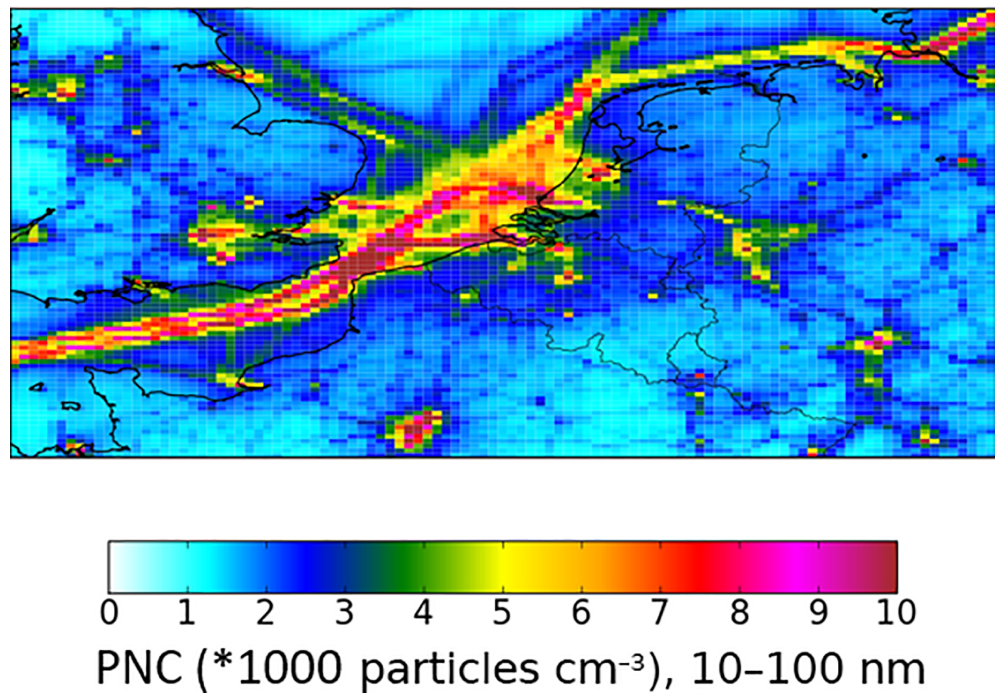

Figure 10. High-resolution modelling of particle number concentrations in the ultrafine range (10-100 nm), annual mean value for 2009.

with emission timing and poor representation of mixing during stagnant conditions. Inefficient heterogeneous chemistry could also play a role in the underestimation by underestimating the conversion of $\mathrm{SO}_{2}$ to $\mathrm{SO}_{4}$. As indicated above, another part of the missing PM must come from secondary organic aerosol. The VBS approach seems a good starting point (Bergström et al., 2012), but not all issues are solved yet. Next to the current 1-D VBS scheme, 2-D schemes have been developed, taking into account not only the saturation vapour pressure but also the $\mathrm{O}: \mathrm{C}$ ratio (oxygenation state) (Donahue et al., 2011). In addition, the importance and pathways of reactive nitrogen were demonstrated by Pye et al. $(2010,2015)$. Reactive nitrogen is not yet taken into account. These developments have contributed to a better description in other studies (Pye et al., 2013). But also using a better emission inventory for $\mathrm{OC}$, including the condensable fraction of the aerosol directly in the emission inventory (Denier van der Gon et al., 2015), made a large difference in bridging the gap. The improvement of emissions and emissions modelling (e.g. Mues et al., 2014; Hendriks et al., 2016b) is and will be one of the focal points of LOTOS-EUROS development and application. It brings together expertise on emission inventorying and data assimilation. Improvements in absolute quantity, spatial distribution and time distribution are possible as more detailed information becomes available in terms of reporting, near-real-time activity data and satellite observation. The variability of emissions with meteorological conditions will also be modelled more explicitly in the future (e.g. more advanced soil $\mathrm{NO}_{x}$ emissions, manure spreading, heating degree days). Natural emissions of $\mathrm{NO}_{x}$ from soil are dependent on soil type, soil moisture, precipitation and evaporation, and temperature. An improved description of soil $\mathrm{NO}_{x}$ emissions was developed (Dammers, 2013), making use of more detailed soil characteristics like soil moisture, but as yet this was not implemented in an official model release. More differentiated time profiles become even more important when going to higher resolution.

More detailed land cover information is required for improved model performance, in particular now that the model is applied over different regions in the world. A step forward would be the harmonization of all soil characteristics, vegetation maps and land use maps necessary for the calculation of natural emissions and for deposition. A future development would be to include a roughness length map instead of a using fixed roughness length for land use categories (e.g. Menut et al., 2013b), which is particularly relevant for areas which are classified as desert but in which the nature of this desert varies strongly per region. This could be achieved relatively easily. In addition, areas may be partly covered by vegetation during part of the year and bare during other seasons, which is not taken into account yet and leads to overestimations of dust emissions or deposition for some regions. A better incorporation of knowledge of local agricultural practices would be needed in order to determine when and where large areas of agricultural land are susceptible to wind erosion, and when dust emitting activities like ploughing or harvesting take place (Schaap et al., 2009). Such a calendar for agricultural activities is implemented in LOTOS-EUROS for Europe. Technically it is easy to adapt this calendar, but it has not been done for other regions. Deposition on vegetation, pollen release and release of biogenic VOCs would benefit from vegetation indices that go beyond climatological growing-season descriptions. Satellite-based vegetation indices could be used, even near-real time. This would be a relevant development in terms of modelling soilbiosphere-atmosphere exchange, which is getting more attention in view of Earth system modelling and understanding of chemical cycles of $\mathrm{N}$ or $\mathrm{CO}_{2}$ budgets. This would, how- 
ever, include an additional data stream, and the gain in model performance is still uncertain.

A recent development in regional-scale chemistry transport models is to run at high resolution (e.g. Colette et al., 2014 at $2 \mathrm{~km}$ resolution, Kuik et al., 2016 at $1 \mathrm{~km}$ resolution) to describe strong gradients within cities. Next to representing strong gradients in cities, for some areas with intensive agriculture, it is desirable to calculate ammonia concentrations and deposition at this high resolution so that the model can be better used for regulatory purposes. LOTOSEUROS is being developed to function at this high resolution. In particular the vertical structure has to be adapted with more vertical sub-layers in the mixing layer. The efficient use of mixing layers and reservoir layers has been one of the distinguishing features of the model but is out of balance at high resolution. A version in which more vertical layers are implemented without losing the model's characteristic efficiency is under construction. The concept is to relate the model's vertical layer structure to the vertical layers of the driving meteorological model, combining a few of them in a single LOTOS-EUROS layer. For high-resolution applications meteorology at higher resolution than now available from ECWMF is required. Such high-resolution meteorology is available from regional models like WRF and regional models operational at European weather institutes (e.g. HARMONIE, COSMO, http://www. cosmo-model.org/), both consortium models of several national weather institutes) that are aimed at short-term forecasts at high resolution. Interfacing to these meteorologies is under development. To overcome the intrinsic larger computation times at high resolution, the implementation of domain decomposition would be necessary to enable efficient parallel computing.

Alternatives for a high resolution of LOTOS-EUROS itself are the implementation of a plume in grid approach (Seigneur et al., 1983; Karamchandani et al., 2011; Rissman et al., 2013) and the (offline) coupling with plume or street models (Brandt et al., 2001; Kukkonen et al., 2016). An intermediate solution for the calculation of annual-average maps has been demonstrated for the Netherlands by combining the LOTOS-EUROS results with those of the Dutch Operational Prioritary Substances (OPS) model (Van Jaarsveld, 2004; Sauter et al., 2015), which is based on Gaussian dispersion. Van der Swaluw et al. (2017) describe how model outputs were combined in such a way that contributions to concentrations in the Netherlands that stemmed from Dutch emission sources were obtained at high resolution from OPS and contributions from abroad were delivered by LOTOSEUROS. This intermediate approach is useful for certain applications; however, it does not fully exploit the possibilities of a full plume-in-grid approach in which the plume and the regional-scale model interact at each time step.

The development towards high resolution is largely a technical one. Societal needs will involve more than high resolution. These include questions related to more detailed health- and climate-related scenarios, such as emission and transport of ultrafine particles and man-made particles including nanomaterials, emissions and monitoring of species related to shale gas production. Operational services like CAMS and new satellites that will be launched in the (near) future will push the generation and use of data streams to the next level. Not only air quality is relevant, but derived quantities like forecasting solar energy are also emerging. Areas which receive much solar radiation in cloud-free conditions suffer most from dust. On the input side, near-real-time data on land cover, vegetation height, etc., could improve model performance. The increased level of detail that is represented in the denser network of ground-based and satellite observations can only be mimicked if the model input is in the same detail, since process parameterizations in the model are generic with as little tuning as possible.

The wealth of new input data, verification data, societal and scientific questions ensures that modelling of atmospheric composition is still a lively field of research and LOTOS-EUROS has the potential for further development to meet future needs.

Code availability. LOTOS-EUROS is written in FORTRAN90 and uses NetCDF libraries and Python scripts. The open-source version of LOTOS-EUROS can be obtained through https://lotos-euros.tno. nl/open-source-version/. Additional functionalities can be disclosed upon request (astrid.manders@tno.nl).

Author contributions. AM prepared the text with the contributions of other authors and contributed to the development, validation, and applications of LOTOS-EUROS. PB contributed to LOTOS development, applications of LOTOS-EUROS, and prepared the description of model history. LC contributed to data assimilation applications. HDvdG, JK, and AV contributed to the emissions input. $\mathrm{CH}$ contributed to model validation, ammonia emissions, and scenario simulations. SJ and EvdS contributed to model development and applications. RK contribution to model development, labelling, and deposition. RT contributed to data assimilation, OSSE, and operational forecasting. AS contributed to data assimilation and CAMS, model development, and dust modelling. AvP contributed to the development of EUROS and to model applications. FS contributed to the model development of EUROS, LOTOS-EUROS, and applications. DS contributed to operational smog forecasting in the Netherlands. RWK contributed to model development (SIA, compensation point) and to applications. HE contributed to data assimilation and forecasting. JD contributed to model applications (CAMS). EvM and $\mathrm{BvU}$ contributed to RACMO coupling and climate scenario simulations. PvV contributed to operational forecasting. AM contributed to climate scenario analysis and emission timing. SB developed cloud chemistry and the wet deposition approach and also contributed to the scenario analysis. RS contributed to LOTOS development. GF, SL, AH, and NvV contributed to the development of the data assimilation system. MS provided major contributions to text and to the development and applications of LOTOS and LOTOS-EUROS. 
Competing interests. The authors declare that they have no conflict of interest.

Acknowledgements. The authors thank all other contributors to LOTOS-EUROS, they are too many to be named explicitly. We would also like to thank EMEP for providing the data from the EBAS dataset. The constructive comments of Laurence Rouil and an anonymous referee are gratefully acknowledged.

Edited by: Holger Tost

Reviewed by: Laurence Rouil and one anonymous referee

\section{References}

Amann, M., Bertok, I., Borken-Kleefeld, J., Cofala, J., Heyers, C., Höglund-Isaksson, Klimont, Z., Nguyen, N., Posch, M., Rafaj, P., Sandler, R., Schöpp, W., Wagner, F., and Winiwarter, W.: Costeffective control of air quality and greenhouse gases in Europe: Modeling and policy applications, Environ. Modell. Softw., 26, 1489-1501, 2011.

Andersson, C., Langner, J., and Bergstrom, R.: Interannual variations and trends in air pollution over Europe due to cllimate variability during 1958-2001 simulated with a regional CTM coupled to the ERA-40 reanalysis, Tellus, 59, 77-98, 2007.

Baklanov, A., Schlünzen, K., Suppan, P., Baldasano, J., Brunner, D., Aksoyoglu, S., Carmichael, G., Douros, J., Flemming, J., Forkel, R., Galmarini, S., Gauss, M., Grell, G., Hirtl, M., Joffre, S., Jorba, O., Kaas, E., Kaasik, M., Kallos, G., Kong, X., Korsholm, U., Kurganskiy, A., Kushta, J., Lohmann, U., Mahura, A., Manders-Groot, A., Maurizi, A., Moussiopoulos, N., Rao, S. T., Savage, N., Seigneur, C., Sokhi, R. S., Solazzo, E., Solomos, S., Sørensen, B., Tsegas, G., Vignati, E., Vogel, B., and Zhang, Y.: Online coupled regional meteorology chemistry models in Europe: current status and prospects, Atmos. Chem. Phys., 14, 317-398, https://doi.org/10.5194/acp-14-317-2014, 2014.

Banzhaf, S., Schaap, M., Kerschbaumer, A., Reimer, E., Stern, R., van der Swaluw, E., and Builtjes, P.: Implementation and evaluation of $\mathrm{pH}$-dependent cloud chemistry and wet deposition in the chemical transport model REM-Calgrid, Atmos. Environ., 49, 378-390, 2012.

Banzhaf, S., Schaap, M., Wichink Kruit, R. J., Denier van der Gon, H. A. C., Stern, R., and Builtjes, P. J. H.: Impact of emission changes on secondary inorganic aerosol episodes across Germany, Atmos. Chem. Phys., 13, 1167511693, https://doi.org/10.5194/acp-13-11675-2013, 2013.

Banzhaf, S., Schaap, M., Kranenburg, R., Manders, A. M. M., Segers, A. J., Visschedijk, A. J. H., Denier van der Gon, H. A. C., Kuenen, J. J. P., van Meijgaard, E., van Ulft, L. H., Cofala, J., and Builtjes, P. J. H.: Dynamic model evaluation for secondary inorganic aerosol and its precursors over Europe between 1990 and 2009, Geosci. Model Dev., 8, 1047-1070, https://doi.org/10.5194/gmd-8-1047-2015, 2015.

Barbu, A., Segers, A. J., Schaap, M., Heemink, A., and Builtjes, P. J. H.: A multi-component data assimilation experiment directed to sulphur dioxide and sulphate over Europe, Atmos. Environ., 43, 1622-1631, 2009.
Beltman, J. B., Hendriks, C., Tum, M., and Schaap, M.: The impact of large scale biomass production on ozone air pollution in Europe, Atmos. Environ., 71, 352-363, https://doi.org/10.1016/j.atmosenv.2013.02.019, 2013.

Bender, J., Bergmann, E., Weigel, H.-J., Grünhage, L., Schröder, M., Builtjes, P., Schaap, M., Kranenburg, R., Wichink Kruit, R., Stern, and R., Baumgarten: Anwendung und Überprüfung neuer Methoden zur flächenhaften Bewertung der Auswirkung von bodennahem Ozon auf die Biodiversität terrestrischer Ökosysteme, UBA TEXTE 70/2015 Umweltforschungsplan des Bundesministeriums für Umwelt, Naturschutz, Bau und Reaktorsicherheit, Forschungskennzahl 371163235 UBA-FB 002142/1, 2015.

Bengtsson, L., Andrae, U., Trygve Aspelien, T., Yurii Batrak, Y., Javier Calvo, J., de Rooy, W., Gleeson, E., Hansen-Sass, B., Homleid, M., Hortal, M., Ivarsson, K.-I., Lenderink, G., Niemelä, S., Pagh Nielsen, K., Onvlee, J., Rontu, L., Samuelsson, P., Santos Muñoz, D., Alvaro Subias, A., Tijm, S., Toll, V., Yang, X., Ødegaard, M., and Køltzow, M.: The HARMONIEAROME model configuration in the ALADIN-HIRLAM NWP system, Mon. Weather Rev., 145, 1919-1935, 2017.

Bergström, R., Denier van der Gon, H. A. C., Prévôt, A. S. H., Yttri, K. E., and Simpson, D.: Modelling of organic aerosols over Europe (2002-2007) using a volatility basis set (VBS) framework: application of different assumptions regarding the formation of secondary organic aerosol, Atmos. Chem. Phys., 12, 8499-8527, https://doi.org/10.5194/acp-12-8499-2012, 2012.

Bessagnet, B., Pirovano, G., Mircea, M., Cuvelier, C., Aulinger, A., Calori, G., Ciarelli, G., Manders, A., Stern, R., Tsyro, S., García Vivanco, M., Thunis, P., Pay, M.-T., Colette, A., Couvidat, F., Meleux, F., Rouïl, L., Ung, A., Aksoyoglu, S., Baldasano, J. M., Bieser, J., Briganti, G., Cappelletti, A., D’Isidoro, M., Finardi, S., Kranenburg, R., Silibello, C., Carnevale, C., Aas, W., Dupont, J.-C., Fagerli, H., Gonzalez, L., Menut, L., Prévôt, A. S. H., Roberts, P., and White, L.: Presentation of the EURODELTA III intercomparison exercise - evaluation of the chemistry transport models' performance on criteria pollutants and joint analysis with meteorology, Atmos. Chem. Phys., 16, 12667-12701, https://doi.org/10.5194/acp-16-12667-2016, 2016.

Blond, N., Bel, L., and Vautard, R. Three-dimensional ozone data analysis with an air quality model over the Paris area, J. Geophys. Res.-Atmos., 108, 8564, 2003.

Brandt, J., Christensen, J. H., Frohn, L. M., Palmgren, F., Berkowicz, R., and Zlatev, Z.: Operational air pollution forecasts from European to local scale, Atmos. Environ., 35, Supplement 1, s91-s98, 2001.

Brunner, D., Savage, N., Jorba, O., Eder, E., Giordano, L., Badia, A., Balzarini, A., Baró, R., Bianconi, R., Chemel, C., Curci, G., Forkel, R., Jiménez-Guerrero, P., Hirtl, M., Hodzic, A., Honzak, L, Im, U., Knote, C., Makar, P., Manders-Groot, A., van Meijgaard, E., Neal, L., Pérez, J. L., Pirovano, G., San Jose, R., Schröder, W., Sokhi, R. S., Syrakov, D., Torian, A., Tuccella, P., Werhahn, J., Wolke, R., Yahya, K., Zabkar, R., Zhang, Y., Hogrefe, C., and Galmarini, S.: Comparative analysis of meteorological performance of coupled chemistry-meteorology models in the context of AQMEII phase 2, Atmos. Environ., 115, 470-498, 2014.

Builtjes, P., van de Hout, D., Veldt, C., Huldy, H., Hulshoff, J., Basting, W., and van Aalst, R.: Application of a photochemical dis- 
persion model to the Netherlands and its surroundings, Proc. Of the 11th ITM, Amsterdam, 6121-637, 1980.

Builtjes, P., van den Hout, K., and Reynolds, S. D.: Evaluation of the performance of a photochemical dispersion models in practical applications, Proc 13th ITM, Ile der Embiez, France, 1982.

Builtjes, P., Hendriks, E., Koenen, M., Schaap, M., Banzhaf, S., Kerschbaumer, A., Gauger, T., Nagel, H.-D., Scheuschner, T., and von Schlutow, A.: Erfassung, Prognose und Bewertung von Stoffeintraegen und ihren Wirkungen in Deutschland, MAPESIProject: Modeling of Air Pollutants and Ecosystem Impact, Dessau, 2011 (in German).

Builtjes, P. J. H.: The LOTOS-Long Term Ozone Simulationproject, Summary report TNO report TNO-MW-R92/40, 1992.

Byun, D. W. and Schere, K. L.: Review of the governing equations, computational algorithms, and other components of the Models3 Community Multiscale Air Quality (CMAQ) Modeling System, Appl. Mech. Rev., 59, 51-77, 2006.

Chamberlain, A. C.: Aspects of travel and deposition of aerosol and vaour clouds, A.E.R.E., HP/R 1261, H.M.S.O., 1953.

Colette, A., Bessagnet, B., Meleux, F., Terrenoire, E., and Rouïl, L.: Frontiers in air quality modelling, Geosci. Model Dev., 7, 203210, https://doi.org/10.5194/gmd-7-203-2014, 2014.

Colette, A., Andersson, C., Manders, A., Mar, K., Mircea, M., Pay, M.-T., Raffort, V., Tsyro, S., Cuvelier, C., Adani, M., Bessagnet, B., Bergström, R., Briganti, G., Butler, T., Cappelletti, A., Couvidat, F., D’Isidoro, M., Doumbia, T., Fagerli, H., Granier, C., Heyes, C., Klimont, Z., Ojha, N., Otero, N., Schaap, M., Sindelarova, K., Stegehuis, A. I., Roustan, Y., Vautard, R., van Meijgaard, E., Vivanco, M. G., and Wind, P.: EURODELTATrends, a multi-model experiment of air quality hindcast in Europe over 1990-2010, Geosci. Model Dev., 10, 3255-3276, https://doi.org/10.5194/gmd-10-3255-2017, 2017.

Curier, R. L., Timmermans, R., Calabretta-Jongen, S., Eskes, H., Segers, A., Swart, D., and Schaap, M.: Improving ozone forecasts over Europe by synergistic use of the LOTOS-EUROS chemical transport model and in-situ measurements, Atmos. Environ., 60, 217-226, 2012.

Curier, R. L., Kranenburg, R., Segers, A. J. S., Timmermans, R. M. A., and Schaap, M.: Synergistic use of OMI $\mathrm{NO}_{2}$ tropospheric columns and LOTOS-EUROS to evaluate the $\mathrm{NO}_{x}$ emission trends across Europe, Remote Sens. Environ., 149, 58-69, 2014.

Dammers, E.: Assessment of soil nitrogen oxides emissions and implementation in LOTOS-EUROS, MS Thesis, Eindhoven University of Technology, Eindhoven, 2013.

De Leeuw, F. A. A. M. and van Rheineck Leyssius, H. J.: Modeling study of $\mathrm{SO}_{x}$ and $\mathrm{NO}_{x}$ transport during the January 1985 SMOG episode, Water Air Soil Poll., 51, 357-371, https://doi.org/10.1007/BF00158232, 1990.

Denby, B., Schaap, M., Segers, A., Builtjes, P., and Horalek, J.: Comparison of two data assimilation methods for assessing $\mathrm{PM}_{10}$ exceedances on the European scale, Atmos. Environ., 42, 7122-7134, 2008.

Denier van der Gon, H. A. C., Hulskotte, J. H. J., Visschedijk, A. J. H., and Schaap, M.: A revised estimate of copper emissions from road transport in UNECE-Europe and its impact on predicted copper concentrations, Atmos. Environ., 41, 8697-8710, 2007.
Denier van der Gon, H. A. C., Bergström, R., Fountoukis, C., Johansson, C., Pandis, S. N., Simpson, D., and Visschedijk, A. J. H.: Particulate emissions from residential wood combustion in Europe - revised estimates and an evaluation, Atmos. Chem. Phys., 15, 6503-6519, https://doi.org/10.5194/acp15-6503-2015, 2015.

Dennis, R., Fox, T., Fuentes, M., Gilliland, A., Hanna, S., Hogrefe, C., Irwin, J., Rao, S. T., Scheffe, R., Schere, K., Steyn, D., and Venkatram, A.: A framework for evaluating regional-scale numerical photochemical modeling systems, Environ. Fluid Mech., 10, 471-489, 2010.

Derwent, R. G., Hov, Ø, Asman, W. A. H., Van Jaarsveld, J. A., and de Leeuw, F. A. A. M.: An intercomparison of long-term atmospheric transport models, The budgets of acidifying species for the Netherlands, Atmos. Environ., 23, 1893-1909, 1989.

Derwent, D. G., Simmonds, P. G., Manning, A. J., and Spain, T. G.: Trends over a 20-year period from 1987 to 2007 in surface ozone at the atmospheric research station, Mace Head, Ireland, Atmos. Environ., 41, 9091-9098, https://doi.org/10.1016/j.atmosenv.2007.08.008, 2007.

De Ruyter de Wildt, M., Eskes, H., Manders, A. M. M., Sauter, F. J., Schaap, M., Swart, D., and Van Velthoven, P.: Six-day PM 10 air quality forecasts for the Netherlands with the chemistry transport model LOTOS-EUROS, Atmos. Environ., 45, 5586-5594, https://doi.org/10.1016/j.atmosenv.2011.04.049, 2011.

Donahue, N. M., Robinson, A. L., Stanier, C. O., and Pandis, S. N.: Coupled partitioning, dilution, and chemical aging of semivolatile organics, Environ. Sci. Technol., 40, 2635-2643, 2006.

Donahue, N. M., Robinson, A. L., and Pandis, S. N.: AtmosphericOrganic Particulate Matter: From Smoke to Secondary Organic Aerosol, Atmos. Environ., 43, 94-106, https://doi.org/10.1016/j.atmosenv.2008.09.055, 2009.

Donahue, N. M., Epstein, S. A., Pandis, S. N., and Robinson, A. L.: A two-dimensional volatility basis set: 1. organic-aerosol mixing thermodynamics, Atmos. Chem. Phys., 11, 3303-3318, https://doi.org/10.5194/acp-11-3303-2011, 2011.

EC: Council Directive 1999/30/EC of 22 April 1999 relating to limit values for sulphur dioxide, nitrogen dioxide and oxides of nitrogen, particulate matter and lead in ambient air, 1999.

EC: Directive 2008/50/EC of the European Parliament and of the Council of 21 May 2008 on ambient air quality and cleaner air for Europe, 2008.

EEA: CORINE Land Cover 2000, https://www.eea.europa.eu/ds_ resolveuid/57CA53B3-E922-40A9-9BD4-AC9AC2183ED3, 2000.

EEA: CLC2006 technical guidelines. EEA Technical report 17/2007. ISBN 978-92-9167-968-3, https://www.eea.europa.eu/ ds_resolveuid/6ee7e1406e694f6adacf6cd349aff89a, 2007.

EEA: Air Quality in Europe, EEA Report No. 28/2016, https://doi.org/10.2800/80982, 2016.

Eliassen, A.: The OECD study of long range transport of air pollutants: long range transport modelling, Atmos. Environ., 12, 479487, 1978.

Eliassen, A. and Saltbones, J.: Modelling of long-range transport of sulphur over Europe: A two-year model run and some model experiments, Atmos. Environ., 17, 1457-1473, 1983. 
Environ: Comprehensive air quality model with extensions, User's Guide Version 6.1, ENVIRON International Corporation, California, USA, 2014.

Erisman, J. W. and Schaap, M.: The need for ammonia abatementwith respect to secondary PM reductions in Europe, Environ. Pollut., 129, 159-163, 2004.

Eskes, H., Veefkind, P., Oud-Nijhuis, A., Williams, J., Huijnen, V., de Haan, J., Attié, J.-L., Abida, R., Quesada-Ruiz, S., El Amraoui, L., Ricaud, P., Zbinden, R., Timmermans, R., Segers, A., Curier, L., Lahoz, W., Kujanpää, J., Tamminen, J., and Veihelmann, B.: Impact of Spaceborne Observations on Tropospheric Composition Analysis and Forecast (ISOTROP), Exec_Summary_ESA400010574311-NL-AF_ISOTROP.pdf, available from: https://gsp. esa.int/documents/10192/46710/C4000105743ExS.pdf/

23faed88-4b92-41ef-a45d-aa7c767f6089, last access: $30 \mathrm{Au}-$ gust 2017.

Evensen, G.: Sequential data assimilation with a nonlinear quasigeostrophic model using Monte Carlo methods to forecast error statistics, J. Geophys. Res., 99, 10143-10162, 1994.

Fast, J. D., Gustafson Jr., W. I., Easter, R. C., Zaveri, R. A., Barnard, J. C., Chapman, E. G., Grell, G. A., and Peckham, S. E.: Evolution of ozone, particulates, and aerosol direct radiative forcing in the vicinity of Houston using a fully coupled meteorology-chemistry-aerosol model, J. Geophys. Res.-Atmos., 111, D21305, https://doi.org/10.1029/2005JD006721, 2006.

Flemming, J., Huijnen, V., Arteta, J., Bechtold, P., Beljaars, A., Blechschmidt, A.-M., Diamantakis, M., Engelen, R. J., Gaudel, A., Inness, A., Jones, L., Josse, B., Katragkou, E., Marecal, V., Peuch, V.-H., Richter, A., Schultz, M. G., Stein, O., and Tsikerdekis, A.: Tropospheric chemistry in the Integrated Forecasting System of ECMWF, Geosci. Model Dev., 8, 975-1003, https://doi.org/10.5194/gmd-8-975-2015, 2015.

Fountoukis, C. and Nenes, A.: ISORROPIA II: a computationally efficient thermodynamic equilibrium model for $\mathrm{K}^{+}-\mathrm{Ca}^{2+}$. $\mathrm{Mg}^{2+}-\mathrm{NH}_{4}^{+}-\mathrm{Na}^{+}-\mathrm{SO}_{4}^{2}-\mathrm{NO}_{3}^{-}-\mathrm{Cl}^{-}-\mathrm{H}_{2} \mathrm{O}$ aerosols, Atmos. Chem. Phys., 7, 4639-4659, https://doi.org/10.5194/acp-7-4639-2007, 2007.

Fountoukis, C., Riipinen, I., Denier van der Gon, H. A. C., Charalampidis, P. E., Pilinis, C., Wiedensohler, A., O’Dowd, C., Putaud, J. P., Moerman, M., and Pandis, S. N.: Simulating ultrafine particle formation in Europe using a regional CTM: contribution of primary emissions versus secondary formation to aerosol number concentrations, Atmos. Chem. Phys., 12, 86638677, https://doi.org/10.5194/acp-12-8663-2012, 2012.

Fowler, D., Coyle, M., Skiba, U., Sutton, M. A., Cape, J. N., Reis, S., Sheppard, L. J., Jenkins, A., Grizzetti, B, Galloway, J. N., Vitousek, P., Leach, A., Bouwman, A. F., Butterbach-Bahl, K., Dentener, F., Stevenson, D., Amann, M., and Voss, M.: The global nitrogen cycle in the twenty-first century, Philos. T. Roy. Soc. B., 368, 20130164, https://doi.org/10.1098/rstb.2013.0164, 2013.

Fox, D. G.: Judging air quality model performance, B. Am. Meteorol. Soc., 62, 599-609, 1981.

Fu, G., Lin, H. X., Heemink, A. W., Segers, A. J., Lu, S., and Palsson, T.: Assimilating aircraft-based measurements to improve forecast accuracy of volcanic ash transport, Atmos. Environ., 115, 170-184, https://doi.org/10.1016/j.atmosenv.2015.05.061, 2015.
Garcia Vivanco, M., Bessagnet, B., Cuvelier, K., Theobald, M. R., Tsyro, S., Aulinger, A., Bieser, J., Calori, G., Ciarelli, G., Manders, A., Mircea, M., Aksoyoglu, S., Briganti, G., Colette, A., Couvidat, F., Cappelletti, A., D'Isidoro, M., Kranenburg, R., Meleux, F., Menut, L., Pay, M.-T., Pirovano, G., Rouil, L., Silibello, C., Thunis, P., and Ung, A.: Joint analysis of deposition fluxes and atmospheric concentrations predicted by six chemistry transport models in the frame of the EURODELTAIII project, Atmos. Environ., 151, 152-175, https://doi.org/10.1016/j.atmosenv.2016.11.042, 2017.

Gery, M. W., Whitten, G. Z., Killus, J. P., and Dodge, M. C.: A photochemical kinetics mechanism for urban and regional scale computer modeling, J. Geophys. Res., 94, 12925-12956, https://doi.org/10.1029/JD094iD10p12925, 1989.

Grell, G. A., Peckham, S. E., Schmitz, R., and McKeen, S. A.: Fully coupled "online" chemistry within the WRF model, Atmos. Environ., 39, 6957-6975, 2005.

Guenther, A., Karl, T., Harley, P., Wiedinmyer, C., Palmer, P. I., and Geron, C.: Estimates of global terrestrial isoprene emissions using MEGAN (Model of Emissions of Gases and Aerosols from Nature), Atmos. Chem. Phys., 6, 3181-3210, https://doi.org/10.5194/acp-6-3181-2006, 2006.

Haagen-Smit, A. J.: Chemistry and Physiology of Los Angelos Smog, Ind. Eng. Chem., 44, 1342-1346, 1952.

Hamm, N. A. S., Finley, A. O., Schaap, M., and Stein, A.: A spatially varying coefficient model for mapping $\mathrm{PM}_{10}$ air quality at the European scale, Atmos. Environ., 102, 393-405, 2015.

Hammingh, P., Thé, H., de Leeuw, F., Sauter, F., van Pul, A., and Matthijsen, J.: A Comparisonof 3 Simplified Chemical Mechanisms for Tropospheric Ozone Modeling, in: Proceedings of EUROTRAC Symposium, edited by: Midgley, J., Reuther, P. M., and Williams, M. J., Garmisch-Partenkirchen, Germany, Proceedings of EUROTRAC Symposium, 2001.

Hanea, R. G., Velders, G. J. M., and Heemink, A.: Data assimilation of ground-level ozone in Europe with a Kalman filter and chemistry transport model, J. Geophys. Res., 109, D10302, https://doi.org/10.1029/2003JD004283, 2004.

Hass, H., Builtjes, P. J. H., Simpson, D., and Stern, R.: Comparison of model results obtained with several european regional air quality models, Atmos. Environ., 31, 3259-3279, https://doi.org/10.1016/S1352-2310(97)00066-6, 1997.

Hendriks, C., Kranenburg, R., Kuenen, J., van Gijlswijk, R., Wichink Kruit, R., Segers, A., Denier van der Gon, H., and Schaap, M.: The origin of ambient particulate matter concentrations in the Netherlands, Atmos. Environ., 69, 289-303, https://doi.org/10.1016/j.atmosenv.2012.12.017, 2013.

Hendriks, C., Kuenen, J. J. P., Kranenburg, R., Scholz, Y., and Schaap, M.: A shift in emission time profiles of fossil fuel combustion due to energy transitions impacts source receptor matrices for air quality, Environmental Science: Processes \& Impacts, 17, 510-524, https://doi.org/10.1039/C4EM00444B, 2015.

Hendriks, C., Forsell, N., Kiesewetter, G., Schaap, M., and Schöpp, W.: Ozone concentrations and damage for realistic future European climate and air quality scenarios, Atmos. Environ., 144, 208-219, 2016a.

Hendriks, C., Kranenburg, R., Kuenen, J. J. P., Van den Bril, B., Verguts, V., and Schaap, M.: Ammonia emission time profiles based on manure transport data improve ammonia mod- 
elling across north western Europe, Atmos. Environ., 131, 8396, https://doi.org/10.1016/j.atmosenv.2016.01.043, 2016b.

Horálek, J., Kurfürst, P., Denby, P., de Smet, P., de Leeuw, F., Brabec, M., and Fiala, J.: Interpolation and assimilation methods for European scale air quality assessment and mapping. Part II: Development and testing new methodologies, ETC/ACC Technical paper 2005/8, 2005.

Horálek, J., Kurfürst, P., de Smet, P., de Leeuw, F., Swart, R., van Noije, T., and Denby, B.: Spatial mapping of air quality for European scale assessment, ETC/ACC Technical Paper 2006/6, 2007.

Im, U., Bianconi, Solazzo, E., Kioutsioukis, I., Badia, A., Balzarini, A., Baró, R., Bellasio, R., Brunner, D., Chemel, C., Curci, G., Flemming, J., Forkel, R., Giordano, L., Jiménez-Guerrero, P., Hirtl, M., Hodzic, A., Honzak, L., Jorba, O., Knote, C., Kuenen, J. J. P., Makar, P. A., Manders-Groot, A., Neal, L., Pérez, J. L., Pirovano, G., Pouliot, G., San Jose, R., Savage, N., Schroder, W., Sokhi, R. S., Syrakov, D., Torian, A., Tuccella, P., Werhahn, J., Wolke, R., Yahya, K., Zabkar, R., Zhang, Y., Zhang, J., Hogrefe, C., and Galmarini, S.: Evaluation of operational on-line-coupled regional air quality models over Europe and North America in the context of AQMEII phase 2. Part I: Ozone, Atmos. Environ., 115, 1-756, 2015a.

Im, U., Bianconi, Solazzo, E., Kioutsioukis, I., Badia, A., Balzarini, A., Baró, R., Bellasio, R., Brunner, D., Chemel, C., Curci, G., Denier van der Gon, H., Flemming, J., Forkel, R., Giordano, L., Jiménez-Guerrero, P., Hirtl, M., Hodzic, A., Honzak, L., Jorba, O., Knote, C., Makar, P. A., Manders-Groot, A., Neal, L., Pérez, J. L., Pirovano, G., Pouliot, G., San Jose, R., Savage, N., Schroder, W., Sokhi, R. S., Syrakov, D., Torian, A., Tuccella, P., Wang, K., Werhahn, J., Wolke, R., Zabkar, R., Zhang, Y., Zhang, J., Hogrefe, C., and Galmarini, S.: Evaluation of operational online-coupled regional air quality models over Europe and North America in the context of AQMEII phase 2. Part II: Particulate matter, Atmos. Environ., 115, 1-756, $2015 \mathrm{~b}$.

Jacob, D. J. and Winner, D. A.: Effect of climate change on air quality, Atmos. Environ., 43, 51-63, 2009.

Jacobs, C. M. J. and Van Pul, W. A. J.: Long-range atmospheric transport of persistant Organic Pollutants, I: Description of surface-atmosphere exchange modules and implementation in EUROS, Tech. rep., Bilthoven, National Institute of Public Health and Environmental Protection (RIVM), Report $722401013,1996$.

Kaiser, J. W., Heil, A., Andreae, M. O., Benedetti, A., Chubarova, N., Jones, L., Morcrette, J.-J., Razinger, M., Schultz, M. G., Suttie, M., and van der Werf, G. R.: Biomass burning emissions estimated with a global fire assimilation system based on observed fire radiative power, Biogeosciences, 9, 527-554, https://doi.org/10.5194/bg-9-527-2012, 2012.

Karamchandani, P., Vijayaraghavan, K., and Yarwood, G.: Sub-Grid Scale Plume Modeling, Atmosphere, 2, 389-406, https://doi.org/10.3390/atmos2030389, 2011.

Katragkou, E., Zanis, P., Tsikerdekis, A., Kapsomenakis, J., Melas, D., Eskes, H., Flemming, J., Huijnen, V., Inness, A., Schultz, M. G., Stein, O., and Zerefos, C. S.: Evaluation of near-surface ozone over Europe from the MACC reanalysis, Geosci. Model Dev., 8, 2299-2314, https://doi.org/10.5194/gmd-8-2299-2015, 2015 .
Koeble, R. and Seufert, G.: Novel maps for forest tree species in Europe, in: Proceedings of the Conference "A Changing Atmosphere", 17-20 September, Torino, Italy, 2001.

Kranenburg, R., Segers, A. J., Hendriks, C., and Schaap, M.: Source apportionment using LOTOS-EUROS: module description and evaluation, Geosci. Model Dev., 6, 721-733, https://doi.org/10.5194/gmd-6-721-2013, 2013.

Kranenburg, R., Quade, M., Dammers, E., Hendriks, C., Van den Bril, B., Verguts, V., and Schaap, M.: Improveing the timing of manuer application emissions for modelling ammonia, Sci. Total Environ., submitted, 2017.

Kuenen, J. J. P., Visschedijk, A. J. H., Jozwicka, M., and Denier van der Gon, H. A. C.: TNO-MACC_II emission inventory; a multi-year (2003-2009) consistent high-resolution European emission inventory for air quality modelling, Atmos. Chem. Phys., 14, 10963-10976, https://doi.org/10.5194/acp-14-109632014, 2014.

Kulmala, M., Lehtinen, K. E. J., and Laaksonen, A.: Cluster activation theory as an explanation of the linear dependence between formation rate of $3 \mathrm{~nm}$ particles and sulphuric acid concentration, Atmos. Chem. Phys., 6, 787-793, https://doi.org/10.5194/acp-6787-2006, 2006.

Kulmala, M., Asmi, A., Lappalainen, H. K., Baltensperger, U., Brenguier, J.-L., Facchini, M. C., Hansson, H.-C., Hov, Ø., O’Dowd, C. D., Pöschl, U., Wiedensohler, A., Boers, R., Boucher, O., de Leeuw, G., Denier van der Gon, H. A. C., Feichter, J., Krejci, R., Laj, P., Lihavainen, H., Lohmann, U., McFiggans, G., Mentel, T., Pilinis, C., Riipinen, I., Schulz, M., Stohl, A., Swietlicki, E., Vignati, E., Alves, C., Amann, M., Ammann, M., Arabas, S., Artaxo, P., Baars, H., Beddows, D. C. S., Bergström, R., Beukes, J. P., Bilde, M., Burkhart, J. F., Canonaco, F., Clegg, S. L., Coe, H., Crumeyrolle, S., D’Anna, B., Decesari, S., Gilardoni, S., Fischer, M., Fjaeraa, A. M., Fountoukis, C., George, C., Gomes, L., Halloran, P., Hamburger, T., Harrison, R. M., Herrmann, H., Hoffmann, T., Hoose, C., Hu, M., Hyvärinen, A., Hõrrak, U., Iinuma, Y., Iversen, T., Josipovic, M., Kanakidou, M., Kiendler-Scharr, A., Kirkevåg, A., Kiss, G., Klimont, Z., Kolmonen, P., Komppula, M., Kristjánsson, J.-E., Laakso, L., Laaksonen, A., Labonnote, L., Lanz, V. A., Lehtinen, K. E. J., Rizzo, L. V., Makkonen, R., Manninen, H. E., McMeeking, G., Merikanto, J., Minikin, A., Mirme, S., Morgan, W. T., Nemitz, E., O’Donnell, D., Panwar, T. S., Pawlowska, H., Petzold, A., Pienaar, J. J., Pio, C., Plass-Duelmer, C., Prévôt, A. S. H., Pryor, S., Reddington, C. L., Roberts, G., Rosenfeld, D., Schwarz, J., Seland, Ø., Sellegri, K., Shen, X. J., Shiraiwa, M., Siebert, H., Sierau, B., Simpson, D., Sun, J. Y., Topping, D., Tunved, P., Vaattovaara, P., Vakkari, V., Veefkind, J. P., Visschedijk, A., Vuollekoski, H., Vuolo, R., Wehner, B., Wildt, J., Woodward, S., Worsnop, D. R., van Zadelhoff, G.J., Zardini, A. A., Zhang, K., van Zyl, P. G., Kerminen, V.M., S Carslaw, K., and Pandis, S. N.: General overview: European Integrated project on Aerosol Cloud Climate and Air Quality interactions (EUCAARI) - integrating aerosol research from nano to global scales, Atmos. Chem. Phys., 11, 13061-13143, https://doi.org/10.5194/acp-11-13061-2011, 2011.

Kukkonen, J., Karl, M., Keuken, M. P., Denier van der Gon, H. A. C., Denby, B. R., Singh, V., Douros, J., Manders, A., Samaras, Z., Moussiopoulos, N., Jonkers, S., Aarnio, M., Karppinen, A., Kangas, L., Lützenkirchen, S., Petäjä, T., Vouitsis, 
I., and Sokhi, R. S.: Modelling the dispersion of particle numbers in five European cities, Geosci. Model Dev., 9, 451-478, https://doi.org/10.5194/gmd-9-451-2016, 2016.

Kuik, F., Lauer, A., Churkina, G., Denier van der Gon, H. A. C., Fenner, D., Mar, K. A., and Butler, T. M.: Air quality modelling in the Berlin-Brandenburg region using WRF-Chem v3.7.1: sensitivity to resolution of model grid and input data, Geosci. Model Dev., 9, 4339-4363, https://doi.org/10.5194/gmd-9-4339-2016, 2016.

Lahoz, W. A., Geer, A. J., Bekki, S., Bormann, N., Ceccherini, S., Elbern, H., Errera, Q., Eskes, H. J., Fonteyn, D., Jackson, D. R., Khattatov, B., Marchand, M., Massart, S., Peuch, V.-H., Rharmili, S., Ridolfi, M., Segers, A., Talagrand, O., Thornton, H. E., Vik, A. F., and von Clarmann, T.: The Assimilation of Envisat data (ASSET) project, Atmos. Chem. Phys., 7, 1773-1796, https://doi.org/10.5194/acp-7-1773-2007, 2007.

Lu, S., Lin, H. X., Heemink, A., Segers, A., and Fu, G.: Estimation of volcanic ash emissions through assimilating satellite data and ground-based observations, J. Geophys. Res.-Atmos., 121, 10971-10994, https://doi.org/10.1002/2016JD025131, 2016.

Mailler, S., Menut, L., Khvorostyanov, D., Valari, M., Couvidat, F., Siour, G., Turquety, S., Briant, R., Tuccella, P., Bessagnet, B., Colette, A., Létinois, L., Markakis, K., and Meleux, F.: CHIMERE-2017: from urban to hemispheric chemistrytransport modeling, Geosci. Model Dev., 10, 2397-2423, https://doi.org/10.5194/gmd-10-2397-2017, 2017.

Manders, A. M. M., Schaap, M., and Hoogerbrugge, R.: Testing the capability of the chemistry transport model LOTOS-EUROS to forecast $\mathrm{PM}_{10}$ levels in the Netherlands, Atmos. Environ., 43, 4050-459 https://doi.org/10.1016/j.atmosenv.2009.05.006, 2009.

Manders, A. M. M., Schaap, M., Querol, X., Albert, M. F. M. A., Vercauteren, J., Kuhlbusch, T. A. J., and Hoogerbrugge, R.: Sea salt concentrations across the European continent, Atmos. Environ., 44, 2434-2442, https://doi.org/10.1016/j.atmosenv.2010.03.028, 2010.

Manders, A. M. M., van Meijgaard, E., Mues, A. C., Kranenburg, R., van Ulft, L. H., and Schaap, M.: The impact of differences in large-scale circulation output from climate models on the regional modeling of ozone and PM, Atmos. Chem. Phys., 12, 9441-9458, https://doi.org/10.5194/acp-12-9441-2012, 2012.

Manders-Groot, A. M. M., Segers, A. J., and Jonkers, S.: LOTOSEUROS v2.0 Reference Guide, TNO report TNO2016 R10898, TNO, Utrecht, the Netherlands, 2016a.

Manders-Groot, A. M. M., Kranenburg, R., and Hendriks, C.: LOTOS-EUROS validation reportv2.0, TNO report TNO2016 R11147, TNO, Utrecht, the Netherlands, 2016b.

Marécal, V., Peuch, V.-H., Andersson, C., Andersson, S., Arteta, J., Beekmann, M., Benedictow, A., Bergström, R., Bessagnet, B., Cansado, A., Chéroux, F., Colette, A., Coman, A., Curier, R. L., Denier van der Gon, H. A. C., Drouin, A., Elbern, H., Emili, E., Engelen, R. J., Eskes, H. J., Foret, G., Friese, E., Gauss, M., Giannaros, C., Guth, J., Joly, M., Jaumouillé, E., Josse, B., Kadygrov, N., Kaiser, J. W., Krajsek, K., Kuenen, J., Kumar, U., Liora, N., Lopez, E., Malherbe, L., Martinez, I., Melas, D., Meleux, F., Menut, L., Moinat, P., Morales, T., Parmentier, J., Piacentini, A., Plu, M., Poupkou, A., Queguiner, S., Robertson, L., Rouïl, L., Schaap, M., Segers, A., Sofiev, M., Tarasson, L., Thomas, M., Timmermans, R., Valdebenito, Á., van
Velthoven, P., van Versendaal, R., Vira, J., and Ung, A.: A regional air quality forecasting system over Europe: the MACC-II daily ensemble production, Geosci. Model Dev., 8, 2777-2813, https://doi.org/10.5194/gmd-8-2777-2015, 2015.

Mårtensson, E. M., Nilsson, E. D., De Leeuw, G., Cohen, L. H., and Hansson, H.-C.: Laboratory simulations and parameterization of the primary marine aerosol production, J. Geophys. Res., 108, 4297, https://doi.org/10.1029/2002JD002263, 2003.

Marticorena, B. and Bergametti, G.: Modeling the atmospheric dust cycle: 1. Designof a soil-derived dust emission scheme, J. Geophys. Res., 100, 16415, https://doi.org/10.1029/95JD00690, 1995.

Martins, V., Miranda, A. I., Carvalho, A., Schaap, M., Borrego, C., and Sá, E.: Forest fires impact on air quality over Portugal during the 2003, 2004 and 2005 fire seasons, Sci. Total Environ., 414, 53-62, https://doi.org/10.1016/j.scitotenv.2011.10.007, 2012.

Matthijsen, J., Delobbe, L. L., Sauter, F., and de Waal, L.: Changes of Surface Ozoneover Europe upon the Gothenburg Protocol Abatement of 1990 Reference Emissions, in: Proceedings of EUROTRAC Symposium, edited by: Midgley, P. M., Reuther, M. J., and Williams, M., Garmisch-Partenkirchen, Germany, 2001.

Matthijsen, J., Sauter, F. J., de Waal, E. S., and Jimmink, B. A.: Modelling of particulate matter on a European scale, in: Proceedings of GLOREAM Symposium, edited by: Keller. J. and Andreani-Aksojoglu, S., Wengen, Switzerland, http://www.dmu.dk/atmosphericenvironment/ gloream/eurotrac2002/Glo09matthijsen.pdf (last access: 25 October 2017), 2002.

Mebust, M. R., Eder, B. K., Binkowski, F. S., and Roselle, S. J.:, Models-3 Community multiscale air quality (CMAQ) model aerosol component, 2. Model evaluation, J. Geophys. Res., 108, 4184, https://doi.org/10.1029/2001JD001410, 2003.

Menut, L., Bessagnet, B., Khvorostyanov, D., Beekmann, M., Blond, N., Colette, A., Coll, I., Curci, G., Foret, G., Hodzic, A., Mailler, S., Meleux, F., Monge, J.-L., Pison, I., Siour, G., Turquety, S., Valari, M., Vautard, R., and Vivanco, M. G.: CHIMERE 2013: a model for regional atmospheric composition modelling, Geosci. Model Dev., 6, 981-1028, https://doi.org/10.5194/gmd-6-981-2013, $2013 \mathrm{a}$.

Menut, L., Pérez, C., Haustein, K., Bessagnet, B., Prigent, C., and Alfaro, S.: Impact of surface roughness and soil texture on mineral dust emission fluxes modeling, J. Geophys. Res.-Atmos., 118, 6505-6520, https://doi.org/10.1002/jgrd.50313, 2013b.

Mokhtari, M., Gomes, L., Tulet, P., and Rezoug, T.: Importance of the surface size distribution of erodible material: an improvement on the Dust Entrainment And Deposition (DEAD) Model, Geosci. Model Dev., 5, 581-598, https://doi.org/10.5194/gmd-5581-2012, 2012.

Monahan, E. C., Spiel, D. E., and Davidson, K. L.: A model of marine aerosol generation via whitecaps and wave disruption. Oceanic Whitecaps and their role in air/sea exchange, edited by: Monahan, E. C. and Mac Niocaill, G., 167-174, 1986.

Mues A., Manders, A., Schaap, M., Kerschbaumer, A., Stern, R., and Builtjes, P.: Impact of the extreme meteorological conditions during the summer 2003 in Europe on particulate matter concentrations, Atmos. Environ., 55, 377-391, 2012.

Mues, A., Manders, A., Schaap, M., van Ulft, L. H., van Meijgaard, E., and Builtjes, P.: Differences in particulate matter concentra- 
tions between urban and rural regions under current and changing climate, Atmos. Environ., 80, 232-247, 2013.

Mues, A., Kuenen, J., Hendriks, C., Manders, A., Segers, A., Scholz, Y., Hueglin, C., Builtjes, P., and Schaap, M.: Sensitivity of air pollution simulations with LOTOS-EUROS to the temporal distribution of anthropogenic emissions, Atmos. Chem. Phys., 14, 939-955, https://doi.org/10.5194/acp-14-939-2014, 2014.

Nickel, S., Schröder, W., Wosniok, W., Harmens, H., Frontasyeva, M. V., Alber, R., Aleksiayenak, J., Barandovski, L., Blum, O., Danielsson, H., De Temmermann, L., Dunaev, A. M., Fagerli, H., Godzik, B., Ilyin, I., Jonkers, S., Jeran, Z., Pihl Karlsson, G., Lazo, P., Leblond, S., Liiv, S., Magnússon, S. H., Mankovska, B., Martínez-Abaigar, J., Piispanen, J., Poikolainen, J., Popescu, I. V., Qarri, F., Radnovic, D., Santamaria, S. M., Schaap, M., Skudnik, M., Špirić, Z., Stafilov, T., Steinnes, E., Stihi, C., Suchara, I., Thöni, Thelle Uggerud, H., and Zechmeister, H. G.: Modelling and mapping heavy metal and nitrogen concentrations in moss in 2010 throughout Europe by applying Random Forests models, Atmos. Environ., 156, 146-159, https://doi.org/10.1016/j.atmosenv.2017.02.032, 2017.

Novak, J. H. and Pierce, T. E.: Natural emissions of oxidant precursors, Water Air Soil Poll., 67, 57-77, https://doi.org/10.1007/BF00480814, 1993.

Paasonen, P., Asmi, A., Petäjä, T., Kajos, M. K., Äijälä, M., Junninen, H., Holst, T. Abbatt, J. P. D., Arneth,A., Birmili, W., Denier van der Gon, H., Hamed, A., Hoffer, A, Laakso, L., Laaksonen, A., Leaitch, W. R., Plass-Dülmer, C., Pryor, S. C., Räisänen, P., Swietlicki, E., Wiedensohler, A., Worsnop, D. R., Kerminen, V.-M., and Kulmala, M.: Warming-induced increase in aerosol number concentration likely to moderate climate change, Nat. Geosci., 6, 438-442, https://doi.org/10.1038/NGEO1800, 2013.

Pekar, M., Gusev, A., Pavlova, N., Strukov, B., Erdman, L., Ilyin, I., and Dutchak, S.: Long-range Transport of Selected POPs. Development of Transport Models for Lindane, Polychlorinated Biphenyls, Benzo[a]pyrene. Part I, EMEP/MSC-E Report 2/98, 1998.

Popa, M. E., Segers, A. J., Denier van der Gon, H. A. C., Krol, M. C., Visschedijk, A. J. H., Schaap, M., and Röckmann, T.: Impact of a future $\mathrm{H} 2$ transportation on atmospheric pollution in Europe, Atmos. Environ., 113, 208-222, 2015.

Potempski, S. and Galmarini, S.: Est modus in rebus: analytical properties of multi-model ensembles, Atmos. Chem. Phys., 9, 9471-9489, https://doi.org/10.5194/acp-9-9471-2009, 2009.

Pye, H. O. T., Chan, A. W. H., Barkley, M. P., and Seinfeld, J. H.: Global modeling of organic aerosol: the importance of reactive nitrogen $\left(\mathrm{NO}_{x}\right.$ and $\left.\mathrm{NO}_{3}\right)$, Atmos. Chem. Phys., 10, 1126111276, https://doi.org/10.5194/acp-10-11261-2010, 2010.

Pye, H. O. T., Pinder, R. W., Piletic, I., Xie, Y., Capps, S. L., Lin, Y.-H., Surratt, J. D., Zhang, Z., Gold, A., Luecken, D. J., Hutzell, W. T., Jaoui, M., Offenberg, J. H., Kleindienst, T. E., Lewandowski, M., and Edney, E. O.: Epoxide pathways improve model predictions of isoprene markers and reveal key role of acidity in aerosol formation, Environ. Sci. Technol., 47, 1105611064, https://doi.org/10.1021/es402106h, 2013.

Pye, H. O. T., Luecken, D. J., Xu, L., Boyd, C. M., Ng, N. L., Baker, K., Ayres, B. A., Bash, J. O., Baumann, K., Carter, W. P. L., Edgerton, E., Fry, J. L., Hutzell, W. T., Schwede, D., and Shepson, P. B.: Modeling the current and future roles of partic- ulate organic nitrates in the southeastern United States, Environ. Sci. Technol., 49, 14195-14203, 2015.

Rao, S. T. and Visalli, J. R.: On the comparative assessment of the performance of air quality models, JAPCA J. Air Waste Ma., 31, 851-860, 1981.

Reynolds, S. D., Roth, P. M., and Seinfeld, J. H.: Mathematical modelling of photochemical air pollution, Atmos. Environ., 7, 1033-1061, https://doi.org/10.1016/0004-6981(73)90214-X, 1973.

Rissman, J., Arunachalam, S., Woody, M., West, J. J., BenDor, T., and Binkowski, F. S.: A plume-in-grid approach to characterize air quality impacts of aircraft emissions at the Hartsfield-Jackson Atlanta International Airport, Atmos. Chem. Phys., 13, 92859302, https://doi.org/10.5194/acp-13-9285-2013, 2013.

Roemer, M., Bergström,, R., Beekmann, M., Boerse, G., Feldmann, H., Flatoj, F., Honore, C., Langners, J., Jonson, J., Matthijsen, J., Memmesheimer, M., Simpson, D., Smeets, P., Solberg, S., Stern., R., Stevenson, D., Zandveld, P., and Zlatev, Z.: Ozone trends according to ten dispersion models, Eurotrac report, Eurotrac-ISS, Garmisch-Partenkirchen, Germany, 2003.

Rohde, H.: A study of the sulfur budget for the atmosphere over northern Europe, Tellus, 24, 128-138, https://doi.org/10.1111/j.2153-3490.1972.tb01540.x, 1972.

Ryaboshapko, A., Bullock, R., Ebinghaus, R., Ilyin, I., Lohman,K., Munthe, J., Petersen, G., Seigneur, C., and Wangberg, I.: Comparison of Mercury Chemistry Models, Atmos. Environ., 36, 3881-3898, 2002.

Sauter, F., van Jaarsveld, J. A., van Zanten, M. C., van der Swaluw, E., Aben, J., and de Leeuw, F.: The OPS-model. Description of OPS 4.4.4, http://www.rivm.nl/media/ops/OPS-model.pdf (last access: 25 October 2017), 2015.

Schaap, M., van Loon, M., ten Brink, H. M., Dentener, F. J., and Builtjes, P. J. H.: Secondary inorganic aerosol simulations for Europe with special attention to nitrate, Atmos. Chem. Phys., 4, 857-874, https://doi.org/10.5194/acp-4-857-2004, 2004a.

Schaap, M., Van Der Gon, H., Dentener, F. J., Visschedijk, A. J. H., and Van Loon, M.: Anthropogenic black carbon and fine aerosol distribution over Europe, J. Geophys. Res., 109, D18207, https://doi.org/10.1029/2003JD004330, 2004b.

Schaap, M., Roemer, M., Sauter, F., Boersen, G., Timmermans, R. M. A., and Builtjes, P. J. H.: LOTOS-EUROS documentation, TNO report B\&O 2005/297, TNO, Apeldoorn, the Netherlands, 2005.

Schaap, M., Timmermans, R. M. A., Sauter, F. J., Roemer, M., Velders, G. J. M., Boersen, G. A. C., Beck, J. P., and Builtjes, P. J. H.: The LOTOS-EUROS model: description, validation and latest developments, Int. J. Environ. Pollut., 32, 270-290, 2008.

Schaap, M., Manders, A. M. M., Hendriks, E. C. J., Cnossen, J. M., Segers, A. J. S., Denier van der Gon, H. A. C., Jozwicka, M., Sauter, F. J., Velders, G. J. M., Matthijsen, J., and Builtjes, P. J. H.: Regional Modelling of Particulate Matter for the Netherlands, PBL report 500099008, Bilthoven, the Netherlands, http:// www.rivm.nl/bibliotheek/rapporten/500099008.pdf (last access: 25 October 2017), 2009.

Schaap, M., Kranenburg, R., Curier, L., Jozwicka, M., Dammers, E., and Timmermans, R.: Assessing the sensitivity of the OMI$\mathrm{NO}_{2}$ product to emission changes across Europe, Remote Sensing, 5, 4187-4208, https://doi.org/10.3390/rs5094187, 2013. 
Schaap, M., Banzhaf, S., Scheuschner, T., Geupel, M., Hendriks, C., Kranenburg, R., Nagel, H. D., Segers, A. J., Von Schlutow, A., Wichink Kruit, R., and Builtjes, P. J. H.: Atmospheric nitrogen deposition to terrestrial ecosystems across Germany, Biogeosciences, in preparation, 2017.

Schell, B., Ackermann, I. J., Hass, H., Binkowski, F. S., and Ebel A.: Modeling the formation of secondary organic aerosol within a comprehensive air quality model system, J. Geophys. Res., 106, 275-228, https://doi.org/10.1029/2001JD000384, 2001.

Scott, B. C.: Parameterization of sulfate removal by precipitation, J. Appl. Meteorol., 17, 1375-1389, https://doi.org/10.1175/15200450(1978)017<1375:POSRBP>2.0.CO;2, 1978.

Segers, A. J., Timmermans, R. M. A., Schaap, M., and Builtjes, P. J. H.: Study on the value of the MSG/SEVIRI derived AOD for operational air quality forecast, TNO report, TNO-034-UT-201000085, 2010.

Seigneur, C., Tesche, T., Roth, P., and Liu, M.: On the treatment of point source emissions in urban air quality modeling, Atmos. Environ., 17, 1655-1676, 1983.

Seinfeld, J. H. and Pandis, S. N.: Atmospheric Chemistry and Physics: from air pollution to climate change, WileyInterscience, Hoboken, N.J., 2006.

Shrivastava, M. K., Lane, T. E., Donahue, N. M., Pandis, S. N., and Robinson, A. L.: Effects of gas particle partitioning and aging of primary emissions on urban and regional organic aerosol concentrations, J. Geophys. Res., 113, D18301, https://doi.org/10.1029/2007JD009735, 2008.

Simpson, D., Fagerli, H., Jonson, J. E., Tsyro, S., Wind, P., and Tuovinen, J.-P.: Transpboundary acidification, autrophication and grond level ozone in Europe, Part 1 Unified EMEP model description EMEP report 1/2003, Norwegina meteorological institute, Oslo, Norway, 2003.

Simpson, D., Benedictow, A., Berge, H., Bergström, R., Emberson, L. D., Fagerli, H., Flechard, C. R., Hayman, G. D., Gauss, M., Jonson, J. E., Jenkin, M. E., Nyíri, A., Richter, C., Semeena, V. S., Tsyro, S., Tuovinen, J.-P., Valdebenito, Á., and Wind, P.: The EMEP MSC-W chemical transport model - technical description, Atmos. Chem. Phys., 12, 7825-7865, https://doi.org/10.5194/acp-12-7825-2012, 2012.

Skjøth, C. A., Hertel, O., and Gyldenkærne, S.: Ellermann, Implementing a dynamical ammonia emission parameterization in the large-scale air pollution model ACDEP, J. Geophys. Res., 109, D06306, https://doi.org/10.1029/2003JD003895, 2004

Skjøth, C. A., Geels, C., Berge, H., Gyldenkærne, S., Fagerli, H., Ellermann, T., Frohn, L. M., Christensen, J., Hansen, K. M., Hansen, K., and Hertel, O.: Spatial and temporal variations in ammonia emissions - a freely accessible model code for Europe, Atmos. Chem. Phys., 11, 5221-5236, https://doi.org/10.5194/acp-11-5221-2011, 2011.

Sofiev, M., Berger, U., Prank, M., Vira, J., Arteta, J., Belmonte, J., Bergmann, K.-C., Chéroux, F., Elbern, H., Friese, E., Galan, C., Gehrig, R., Khvorostyanov, D., Kranenburg, R., Kumar, U., Marécal, V., Meleux, F., Menut, L., Pessi, A.-M., Robertson, L., Ritenberga, O., Rodinkova, V., Saarto, A., Segers, A., Severova, E., Sauliene, I., Siljamo, P., Steensen, B. M., Teinemaa, E., Thibaudon, M., and Peuch, V.-H.: MACC regional multi-model ensemble simulations of birch pollen dispersion in Europe, Atmos. Chem. Phys., 15, 8115-8130, https://doi.org/10.5194/acp15-8115-2015, 2015.
Solazzo, E. and Galmarini, S.: Error apportionment for atmospheric chemistry-transport models - a new approach to model evaluation, Atmos. Chem. Phys., 16, 6263-6283, https://doi.org/10.5194/acp-16-6263-2016, 2016.

Solazzo, E., Bianconi, R., Pirovano, G., Matthias, V., Vautard, R., Morann, M. D., Wyat Appel, K., Bessagnet, B., Brandt, J., Christensen, J. H., Chemel, C., Collo, I., Ferreira, J., Forkel, R., Francis, X. V., Grell, G., Grossi, P., Hansen, A. B., Miranda, A. I., Nopmongcold, U., Prank, M., Sartelet, K. N., Schaap, M., Silver, J. D., Sokhi, R. D., Viras, J., Werhahn, J., Wolke, R., and Yarwood, G.: AQMEII: An International Initiative for the Evaluation of Regional-Scale Air Quality Models - Phase 1 Operational model evaluation for particulate matter in Europe and North America in the context of AQMEII, Atmos. Environ., 53, 60-74, 2012a.

Solazzo, E., Bianconi, R., Vautard, R., Appel, K. W., Morann, M. D., Hogrefe, C., Bessagnet, B., Brandt, J., Christensen, J. H., Chemel, C., Collo, I., Denier van der Gon, H., Ferreira, J., Forkel, R., Francis, X. V., Grell, G., Grossi, P., Hansen, A. B., Jeričević, A., Kraljević, L., Miranda, A. I., Nopmongcol, U., Pirovano, G., Prank, M., Riccio, A., Sartelet, K. N., Schaap, M., and Silver, J. D.: Model evaluation and ensemble modelling of surface-level ozone in Europe and North America in the context of AQMEII, 53, 75-92, https://doi.org/10.1016/j.atmosenv.2012.02.045, 2012 b.

Stern, R., Yamartino, R., and Graff, A.: Dispersion modelling within the European Community air quality direction, long term modelling of $\mathrm{O}_{3}, \mathrm{PM}_{10}$ and $\mathrm{NO}_{2}$, Proc. 26th ITM, Istanbul, Turkey, 2003.

Stern, R., Builtjes, P. J. H., Schaap, M., Timmermans, R., Vautard, R., Hodzic, A., Memmesheimer, M., Feldmann, H., Renner, E., Wolke, R., and Kerschbaumer, A.: A model inter-comparison study focussing on episodes with elevated $\mathrm{PM}_{10}$ concentrations, Atmos. Environ., 42, 4567-4588, 2008.

Sutton, M. A., Howard, C. M., Bleeker, A., and Datta, A.: The global nutrient challenge: From science to public engagement, Environmental Development, 6, 80-85, https://doi.org/10.1016/j.envdev.2013.03.003, 2013.

Thunis, P., Cuvelier, C., Roberts, P., White, L., Post, L., Tarrason, L., Tsyro, S., Stern, R., Kerschbaumer, A., Rouil, L., Bessagnet, B., Bergström, R., Schaap, M., Boersen, G., and Builtjes, P.: Evaluation of a Sectoral Approach to Integrated Assessment Modelling including the Mediterranean Sea, Tech. rep., Eurodelta II, report EUR $23444 \mathrm{EN}$, https://doi.org/10.2788/87066, 2008.

Thunis, P., Cuvelier, C., Roberts, P., White, L., Nyrni, A., Stern, R., Kerschbaumer, A., Bessagnet, B., Bergström, R., Schaap, M., EUR - Scientific and Technical Research Reports, Publications Office of the European Union, ISBN: 978-92-79-163579, ISSN: 1018-5593, https://doi.org/10.2788/40803, EUR 24474 EN, OPOCE LB-NA-24474-EN-C, 2010.

Timmermans, R. M. A, A. J. Segers, P. J. H. Builtjes, R. Vautard, R. Siddans, H. Elbern, S. A. T. Tjemkes, M. Schaap: The Added Value of a Proposed Satellite Imager for Ground Level Particulate Matter Analyses and Forecasts, IEEE-JSTARS (Journal of Selected Topics in Applied Earth Observations and Remote Sensing), 2, 271-283, https://doi.org/10.1109/JSTARS.2009.2034613, 2009. 
Timmermans, R., Denier van der Gon, H., Kuenen, J., Segers, A., Honore, C., Perrussel, O., Builtjes, P., and Schaap, M.: Quantification of the urban air pollution increment and its dependency on the use of down-scaled and bottomup city emission inventories, Urban Climate, 6, 44-62, https://doi.org/10.1016/j.uclim.2013.10.004, 2013.

Timmermans, R. M. A., Lahoz, W. A., Attié, J.-L., Peuch, V.-H., Curier, R. L., Edwards, D. P., Eskes, H. J., and Builtjes, P. J. H.: Observing System Simulation Experiments for air quality, Atmos. Environ., 115, 199-213, https://doi.org/10.1016/j.atmosenv.2015.05.032, 2015.

Timmermans, R., Kranenburg, R., Manders, A., Hendriks, C., Segers, A., Dammers, E., Zhang, Q., Wang, L., Liu, Z., Denier van der Gon, H., and Schaap, M.: Source apportionment of $\mathrm{PM}_{2.5}$ across China using LOTOS-EUROS, Atmos. Environ., 164, 370-386, https://doi.org/10.1016/j.atmosenv.2017.06.003, 2017.

Tørseth, K., Aas, W., Breivik, K., Fjæraa, A. M., Fiebig, M., Hjellbrekke, A. G., Lund Myhre, C., Solberg, S., and Yttri, K. E.: Introduction to the European Monitoring and Evaluation Programme (EMEP) and observed atmospheric composition change during 1972-2009, Atmos. Chem. Phys., 12, 5447-5481, https://doi.org/10.5194/acp-12-5447-2012, 2012.

Van Damme, M., Wichink Kruit, R. J., Schaap, M., Clarisse, L., Clerbaux, C., Coheur, P.-F., Dammers, E., Dolman, A. J., and Erisman, J. W.: Evaluating 4 years of atmospheric ammonia $\left(\mathrm{NH}_{3}\right)$ over Europe using IASI satellite observations and LOTOS-EUROS model results, J. Geophys. Res.-Atmos., 119, 9549-9566, https://doi.org/10.1002/2014JD021911, 2014.

Van de Kassteele, J., Koelemeijer, R. B. A., Dekkers, A. L. M., Schaap, M., Homan, C. D., and Stein, A.: Statistical mapping of $\mathrm{PM}_{10}$ concentrations over Western Europe using secondary information from dispersion modeling and MODIS satellite observations, Stoch. Env. Res. R. A., 21, 183-194, 2006.

Van de Kassteele, J. and Velders, G. J.: Uncertainty assessment of local $\mathrm{NO}_{2}$ concentrations derived from error-in-variable external drift kriging and its relationship to the 2010 air quality standard, Atmos. Environ., 40, 2583-2595, 2006.

Van der Swaluw, E., de Vries, W. J., Sauter, F. J., Aben, J. M. M., Velders, G. J. M., and van Pul, W. A. J.: High-resolution modelling of air pollution and deposition over the Netherlands with plume, grid and hybrid modelling, Atmos. Environ., 155, 140153, https://doi.org/10.1016/j.atmosenv.2017.02.009, 2017.

van Egmond, N. D. and Kesseboom, H.: Numerieke verspreidingsmodellen voor de interpretatie van de meetresultaten van het nationaal meetnet voor luchtverontreininging, Tech. rep., Bilthoven: RIVM, RIVM Report 227905048, 1981.

Van Jaarsveld, J. A.: The Operational Priority Substances Model, RIVM, Bilthoven, the Netherlands, RIVM Report 500045001, 2004.

Van Loon, M.: Numerical smog prediction, I: The physical and chemical model, Tech. rep., Amsterdam, CWI research report, NM-R9411, ISSN 0169-0388, 1994.

Van Loon, M.: Numerical smog prediction II: grid refinement and its application to the Dutch smog prediction model, Tech. rep., Amsterdam, the Netherlands, CWI, research report, NM-R9523, ISSN 0169-0388, 1995.
Van Loon, M., Builtjes, P. J. H., and Segers, A. J.: Data assimilation of ozone in the atmospheric transport chemistry model LOTOS, Environ. Modell. Softw., 15, 603-609, 2000.

Van Loon, M., Roemer, M. G. M., Builtjes, P. J. H., Bessagnet, B., Rouill, L., Christensen, J., Brandt, J., Fagerli, H., Tarrason, L., Rodgers, I., Stern, R., Bergström, R., Langner, J., and Foltescu, V.: Model-intercomparison in the framework of the review of the unified EMEP-model, TNO-MEPO-R 2004/282, (TNO Report, Vol. 282), 86 pp., 2004.

Van Loon, M., Vautard, R., Schaap, M., Bergström, R., Bessagnet, B., Brandt, J., Builtjes, P. J. H, Christensen, J. H., Cuvelier, K., Graf, A., Jonson, J. E., Krol, M., Langner, J., Roberts, P., Rouil, L., Stern, R., Tarrasón, L., Thunis, P., Vignati, E., White, L., and Wind, P.: Evaluation of long-term ozone simulations from seven regional air quality models and their ensemble average, Atmos. Environ., 41, 2083-2097, 2007.

van Meijgaard, E., van Ulft, L. H., van de Berg, W. J., Bosveld, F. C., van den Hurk, B. J. J. M., Lenderink, G., Siebesma, A. P., and Siebesma, P.: The KNMI regional atmospheric climate model RACMO version 2.1, KNMI technical report TR - 302, 2008.

Van Rheineck Leyssius, H. J., de Leeuw, F. A. A. M., and Kesseboom, B. H.: Aregional scale model for the calculation of episodic concentrations and depositions of acidifying components, Water Air Soil Poll., 51, 327-344, https://doi.org/10.1007/BF00158230, 1990.

Van Velzen, N. and Segers, A. J.: A problem-solving environment for data assimilation in air quality modeling, Environ. Modell. Softw., 25, 277-288, https://doi.org/10.1016/j.envsoft.2009.08.008, 2010.

Van Zanten, M. C., Sauter, F. J., Wichink Kruit, R. J., Van Jaarsveld, J. A., and Van Pul, W. A. J.: Description of the DEPAC module: Dry deposition modelling with DEPAC GCN2010, RIVM report 680180001/2010, Bilthoven, the Netherlands, 74 pp., 2010.

Vautard, R., Schaap, M., Bergström, R., Bessagnet, B., Brandt, J., Builtjes, P. J. H., Christensen, J. H., Cuvelier, C., Foltescu, V., Graff, A., Kerschbaumer, A., Krol, M., Roberts, P., Rouîl, L., Stern, R., Tarrason, L., Thunis, P., Vignati, E., and Wind, P.: Skill and uncertainty of a regional air quality model ensemble, Atmos. Environ., 43, 4822-4832, https://doi.org/10.1016/j.atmosenv.2008.09.083, 2009.

Vehkamaki, H., Kulmala, M., Napari, I., Lehtinen, K. E. J., Timmreck, C., Nopperl, M., and Laaksonen, A.: An improved parameterization for sulfuric acid-water nucleation rates for tropospheric and stratospheric conditions, J. Geophys. Res., 107, 4622, https://doi.org/10.1029/2002JD002184, 2002.

Vignati, E., Wilson, J., and Stier, P.: M7: An efficient size-resolved aerosol microphysics module for large-scale aerosol transport models, J. Geophys. Res., 109, D22202, https://doi.org/10.1029/2003JD004485, 2004.

Wagstrom, K. M., Pandis, S. N., Yarwood, G., Wilson, G. M., and Morris, R. E: Development and application of a computationally efficient particulate matter apportionment algorithm in a three-dimensional chemical transport model, Atmos. Environ., 42, 5650-5659, https://doi.org/10.1016/j.atmosenv.2008.03.012, 2008.

Wichink Kruit, R. J., Van Pul, W. A. J., Sauter, F. J., Van den Broek, M., Nemitz, E., Sutton, M. A., Krol, M., and Holtslag, A. A. M.: Modeling the surface-atmosphere 
exchange of ammonia, Atmos. Environ., 44, 945-957, https://doi.org/10.1016/j.atmosenv.2009.11.049, 2010.

Wichink Kruit, R. J., Schaap, M., Sauter, F. J., van Zanten, M. C., and van Pul, W. A. J.: Modeling the distribution of ammonia across Europe including bi-directional surface-atmosphere exchange, Biogeosciences, 9, 5261-5277, https://doi.org/10.5194/bg-9-5261-2012, 2012a.

Wichink Kruit, R. J., Schaap, M., Sauter, F. J., van der Swaluw, E., and Weijers, E.: Improving the understanding of the secondary inorganic aerosol distribution over the Netherlands, TNO report TNO-060-UT-2012-00334, TNO, Utrecht, the Netherlands, 78 pp., 2012 b.

Zhang, L., Gong, S., Padro, J., and Barrie, L.: A size-segregated particle dry deposition scheme for an atmospheric aerosol module, Atmos. Environ., 39, 3291-3303, 2001.
Zhang, Q. J., Beekmann, M., Drewnick, F., Freutel, F., Schneider, J., Crippa, M., Prevot, A. S. H., Baltensperger, U., Poulain, L., Wiedensohler, A., Sciare, J., Gros, V., Borbon, A., Colomb, A., Michoud, V., Doussin, J.-F., Denier van der Gon, H. A. C., Haeffelin, M., Dupont, J.-C., Siour, G., Petetin, H., Bessagnet, B., Pandis, S. N., Hodzic, A., Sanchez, O., Honoré, C., and Perrussel, O.: Formation of organic aerosol in the Paris region during the MEGAPOLI summer campaign: evaluation of the volatility-basis-set approach within the CHIMERE model, Atmos. Chem. Phys., 13, 5767-5790, https://doi.org/10.5194/acp13-5767-2013, 2013. 